\title{
High-level Expression, Purification, and Enzymatic Characterization of Full-length Thermus aquaticus DNA Polymerase and a Truncated Form Deficient in $5^{\prime}$ to $3^{\prime}$ Exonuclease Activity
}

\author{
Frances C. Lawyer, ${ }^{1}$ Susanne Stoffel, ${ }^{1}$ Randall K. Saiki, ${ }^{2}$ Sheng-Yung Chang, ${ }^{3}$ Phoebe A. Landre, $^{1}$ \\ Richard D. Abramson, ${ }^{1}$ and David H. Gelfand ${ }^{1}$
}

\author{
${ }^{1}$ Program in Core Research and Departments of ${ }^{2}$ Human Genetics and ${ }^{3}$ Infectious Disease, Roche Molecular Systems, \\ Alameda, California 94501
}

The Thermus aquaticus DNA polymerase I (Taq Pol I) gene was cloned into a plasmid expression vector that utilizes the strong bacteriophage $\lambda$ P promoter. A truncated form of Taq Pol I was also constructed. The two constructs made it possible to compare the full-length 832-amino-acid Taq Pol I and a deletion derivative encoding a 544-amino-acid translation product, the Stoffel fragment. Upon heat induction, the 832-aminoacid construct produced $1-2 \%$ of total protein as Taq Pol I. The induced 544-amino-acid construct produced $3 \%$ of total protein as Stoffel fragment. Enzyme purification included cell lysis, heat treatment followed by Polymin P precipitation of nucleic acids, phenyl sepharose column chromatography, and heparin-Sepharose column chromatography. For fulllength 94-kD Taq Pol I, yield was $3.26 \times 10^{7}$ units of activity from 165 grams wet weight cell paste. For the 61-kD Taq Pol I Stoffel fragment, the yield was $1.03 \times 10^{6}$ units of activity from 15.6 grams wet weight cell paste. The two enzymes have maximal activity at $75^{\circ} \mathrm{C}$ to $80^{\circ} \mathrm{C}, 2-4 \mathrm{~mm}$ $\mathrm{MgCl}_{2}$ and $10-55 \mathrm{~mm} \mathrm{KCl}$. The nature of the substrate determines the precise conditions for maximal enzyme activity. For both proteins, $\mathbf{M g C l}_{2}$ is the preferred cofactor compared to $\mathrm{MnCl}_{2}, \mathrm{CoCl}_{2}$, and $\mathrm{NiCl}_{2}$. The fulllength Taq Pol I has an activity half-
Iife of $9 \mathrm{~min}$ at $97.5^{\circ} \mathrm{C}$. The Stoffel fragment has a half-life of $\mathbf{2 1}$ min at 97. $5^{\circ} \mathrm{C}$. Taq Pol I contains a polymerization-dependent $5^{\prime}$ to $3^{\prime}$ exonuclease activity whereas the Stoffel fragment, deleted for the $5^{\prime}$ to $3^{\prime}$ exonuclease domain, does not possess that activity. A comparison is made among thermostable DNA polymerases that have been characterized; specific activities of 292,000 units/mg for Taq Pol I and 369,000 units/mg for the Stoffel fragment are the highest reported.

he thermostable DNA polymerase I (Taq Pol I) from Thermus aquaticus (Taq) greatly improves the yield, specificity, automation, and utility of the polymerase chain reaction (PCR $)^{(1,2)}$ method of amplifying DNA fragments. ${ }^{(3)}$ Furthermore, because of the high turnover number, lack of proofreading activity, high temperature optimum, and ability to incorporate 7-deaza-2-deoxyguanosine efficiently, Taq Pol I yields long stretches of readable DNA sequence that are uniform in intensity and free of background. ${ }^{(4)}$

A 94-kD Taq Pol I has been purified from Taq, but growing the organism is more difficult than growing Escherichia coli. Although the activity yield is high (40-60\%), the expression level of Taq Pol
I in the native host is quite low (0.01$0.02 \%$ of total protein). The cloning and expression of full-length 94-kD Taq Pol I in $E$. coli under control of the $E$. coli lac promoter $^{(5,6)}$ or the tac promoter ${ }^{(7)}$ has been reported. Because polymerase yields in these constructs were low $(\sim 0.01 \%$ of total protein in our initial construct; see ref. 5), we sought to improve the expression level of the enzyme by mutagenizing the $5^{\prime}$ and $3^{\prime}$ ends of the gene and cloning the mutagenized gene into a more suitable expression vector. We also constructed a truncated Taq Pol I gene, deleted for the first 867 bp of the gene, which yields a predicted $61-\mathrm{kD}$ translation product. The $61-\mathrm{kD}$ derivative, Taq Pol I Stoffel fragment, is active in polymerase assays and PCR and is devoid of the inherent $5^{\prime}$ to $3^{\prime}$ exonuclease activity of Taq Pol I. A similarly truncated gene deleted for the first $705 \mathrm{bp}$, has recently been constructed, yielding an approximately $67-\mathrm{kD}$ translation product, KlenTaq DNA polymerase. ${ }^{(8)}$ Protein produced by the two constructs described here provides a plentiful supply of the two forms of Taq Pol I enzyme, thereby enabling their biochemical properties to be investigated. The study of these enzymes not only provides key insights into nucleic acid metabolism, but also provides useful information to those investigators who exploit DNA polymerases in specialized molecular biology techniques, including the PCR. Advancements in PCR methodology 
depend in part on an increased understanding of the biochemistry of thermostable DNA polymerases, as such information aids substantially in the constant refinement of this and other research techniques.

\section{MATERIALS AND METHODS}

\section{Bacterial Strains and Plasmids}

E. coli strain DG98 (thi-1 endA1 hsdR17 lacI $I^{Q}$ lacZ $\triangle M 15$ proC::Tn10 supE44/ F'la$c^{\mathrm{Q}}$ lacZAM15 proC $^{+}$) has been described. ${ }^{(9)}$ E. coli strain DG116 [thi-1 endA1 hsdR17 supE44 ( $\lambda$ cI857 bioT76 $\Delta H 1)$ ] is a derivative of strain MM294 ${ }^{(10)}$ containing a defective $\lambda$ prophage. DG116 was prepared using bacteriophage $\mathrm{P} 1$ transduction ${ }^{(11)}$ and $E$. coli strain $\mathrm{N} 6590\left[\mathrm{C} 600 \mathrm{rK}^{-} \mathrm{mK}^{-}\right.$thr leu pro lacZXA21::Tn10 ( $\mathrm{AcI857}$ bioT76 $\Delta H 1)$, provided by $M$. Gottesman, Columbia University] as the source of the defective prophage. Plasmid $\mathrm{pBS}^{+}$was purchased from Stratagene. Plasmid pFC54.T has been described. ${ }^{(12)}$ Plasmid pDG160, a derivative of pFC54.T, contains a convenient restriction site polylinker between the $\mathrm{P}_{\mathrm{L}}$ promoter and retroregulator cassettes.

\section{Reagents}

Restriction endonucleases [New England Biolabs (NEB)], E. coli DNA polymerase I, large fragment (Klenow) (U.S. Biochemicals), T4 DNA ligase, ${ }^{(13)}$ calf intestine alkaline phosphatase (CIAP) (BoehringerMannheim), and polynucleotide kinase (kinase) (NEB) were used according to standard procedures. Oligonucleotides were phosphorylated as described. (14) Molecular weight standards for SDSpolyacrylamide gel electrophoresis (PAGE) were purchased from Pharmacia $\left[\gamma^{32} \mathrm{P}\right] \mathrm{ATP} \quad(3000 \mathrm{Ci} / \mathrm{mmole})$, $\left[\alpha-{ }^{32} \mathrm{P}\right] \mathrm{dCTP} \quad(800 \mathrm{Ci} / \mathrm{mmole}), \quad$ and $\left[{ }^{3} \mathrm{H}\right] \mathrm{dCTP}(22.8 \mathrm{Ci} / \mathrm{mmole})$, were purchased from New England Nuclear. Oligonucleotide synthesis was performed on a Biosearch Model 8750 DNA synthesizer using controlled-pore glass and $O$-cyanoethyl- $N$, N-diisopropyl phosphoramidites. $^{(15,16)}$ Reagents and synthesis protocols were obtained from Milligen/Biosearch (Novato, CA).

Crude salmon sperm DNA was obtained from Sigma (\#D-1626, Type III) and "activated" by incubation at $4^{\circ} \mathrm{C}$ for $24 \mathrm{hr}$ at $1.3 \mathrm{mg} / \mathrm{ml}$ in $10 \mathrm{~mm}$ Tris- $\mathrm{HCl}$
(pH 7.2), $5 \mathrm{~mm} \quad \mathrm{MgCl}_{2} \cdot{ }^{(17)}$ Singlestranded template DNA was prepared by conventional methods ${ }^{(14)}$ from M13 phage TSYC657 (7.359 kb), a derivative of M13mp10 containing a 129-nucleotide insert derived from a Streptomyces limosus $\alpha$-amylase gene. ${ }^{(18)}$ The 24 -mer synthetic oligodeoxynucleotide primer SC64 (Table 1) is complementary to the S. limosus-derived insert in TSYC657 and has a calculated melting temperature of $95^{\circ} \mathrm{C}$ at $0.12 \mu \mathrm{M}$ in $100 \mathrm{~mm} \mathrm{NaCl}$. Primer and template were annealed at $583 \mathrm{~nm}$ SC64 and $256 \mathrm{~nm}$ TSYC657(2.2:1 primer: template) in $10 \mathrm{~mm}$ Tris- $\mathrm{HCl}(\mathrm{pH} 8.0) 6$ $\mathrm{mM} \mathrm{MgCl}_{2}$, and $50 \mathrm{~mm} \mathrm{KCl}$. The mixture was heated at $95^{\circ} \mathrm{C}$ for $4 \mathrm{~min}$, incubated at $70^{\circ} \mathrm{C}$ for $10 \mathrm{~min}$, and cooled to room temperature.

\section{Cloning Procedures}

For oligonucleotide site-directed mutagenesis, single-stranded DNA was prepared from $\mathrm{pBS}^{+}$plasmid derivatives pLSG1 and pLSG2 as described. (5) Competent cells were prepared and transformations were carried out by the method of Hanahan. ${ }^{(19)}$ Alkaline-SDS miniplasmid DNA preparations were carried out by the method of Birnboim and Doly. ${ }^{(20)}$ Enzymatic dideoxynucleotide DNA sequence analysis ${ }^{(21)}$ confirmed all DNA sequence alterations.

\section{Oligonucleotide Site-directed Mutagenesis(22)}

For pLSG1 mutagenesis, 0.24 pmole of single-stranded pLSG1, 0.36 pmole of PvuII-digested CIAP-treated vector $\mathrm{pBS}^{+}$, and 0.48 pmole of primer DG26 (Table 1) were annealed. The mixture was put on ice and TTP, dGTP, dATP, $\left[{ }^{3} \mathrm{H}\right] \mathrm{dCTP}$ were each added to $200 \mu \mathrm{M}$ along with 1 unit of Klenow fragment. The extension mixture was incubated at $0^{\circ} \mathrm{C}$ for $30 \mathrm{~min}$ and then at $30^{\circ} \mathrm{C}$ for $30 \mathrm{~min}$. The reac- tion products were transformed into DG98. Nitrocellulose filters containing ampicillin-resistant transformants were hybridized according to the method of Woods et al. ${ }^{(23)}$ with ${ }^{32}$ P-labeled DG26 probe. Positive colonies were picked and screened by restriction analysis of alkaline-SDS miniplasmid preparations. A representative correct candidate was designated pLSG2 (Fig. 1).

For mutagenesis of pLSG2, 0.5 pmole of single-stranded pLSG2, 0.5 pmole of PvuII-digested, CIAP-treated $\mathrm{pBS}^{+}$, and 2.5 pmoles of oligonucleotide $\mathrm{SC} 107$ (Table 1) were annealed. Extension, transformation, and screening were performed as described above, using ${ }^{32} \mathrm{P}$-labeled $\mathrm{SC} 107$ as the probe. A representative correct candidate was designated pSYC1578 (Fig. 1).

\section{Assembly of a Full-length Taq Pol I Gene in High-level Expression Vectors}

An SphI and BglII-digest of pSYC1578 DNA was ligated with HindIII- and BamHI-digested vector pFC54.T and an annealed duplex oligonucleotide, DG27/ 28 (Table 1). The oligonucleotide duplex provided HindIII and SphI cohesive ends and codons one, two, and two of three nucleotides for codon three of Taq Pol I. The resulting plasmid was designated pLSG5 (Fig. 1).

\section{Assembly of a Truncated Taq Pol I Gene}

A BstXI digest of pSYC1578 was treated with Klenow to generate blunt ends. The DNA was then treated with BglII and a 1619-bp BstXI-blunt-BglII fragment (encoding Taq Pol I codons 294-832) was isolated via gel electrophoresis and electroelution. The isolated DNA fragment was ligated to HindIII- and BamHI-digested vector $\mathrm{pFC54.T}$ and an annealed

TABLE 1 Oligonucleotides Used in These Studies
DG26
DG27
DG28
5'-CCCTTGGGCTCAAAAAGTGGAAGCATGCCTCTCATAGCTGTTTCCTG
DG29
DG30
5'-AGCTTATGAGAGGCATG
ATACTCTCC-5
5'-AGCTTATGTCTCCAAAAGCT ATACAGAGGTTTTCGA-5
DG48 5'-GGGAAGGGCGATCGGTGCGGGCCTCTTCGC
DG67 5'-CCCGGGCGGCGCCGCAGCGGCGGGp
SC64 5'-CCCGGGCGGCGCCGCAGCGGCGGG
SC107 5'-GCATGGGGTGGTAGATCTCACTCCTTGGC 


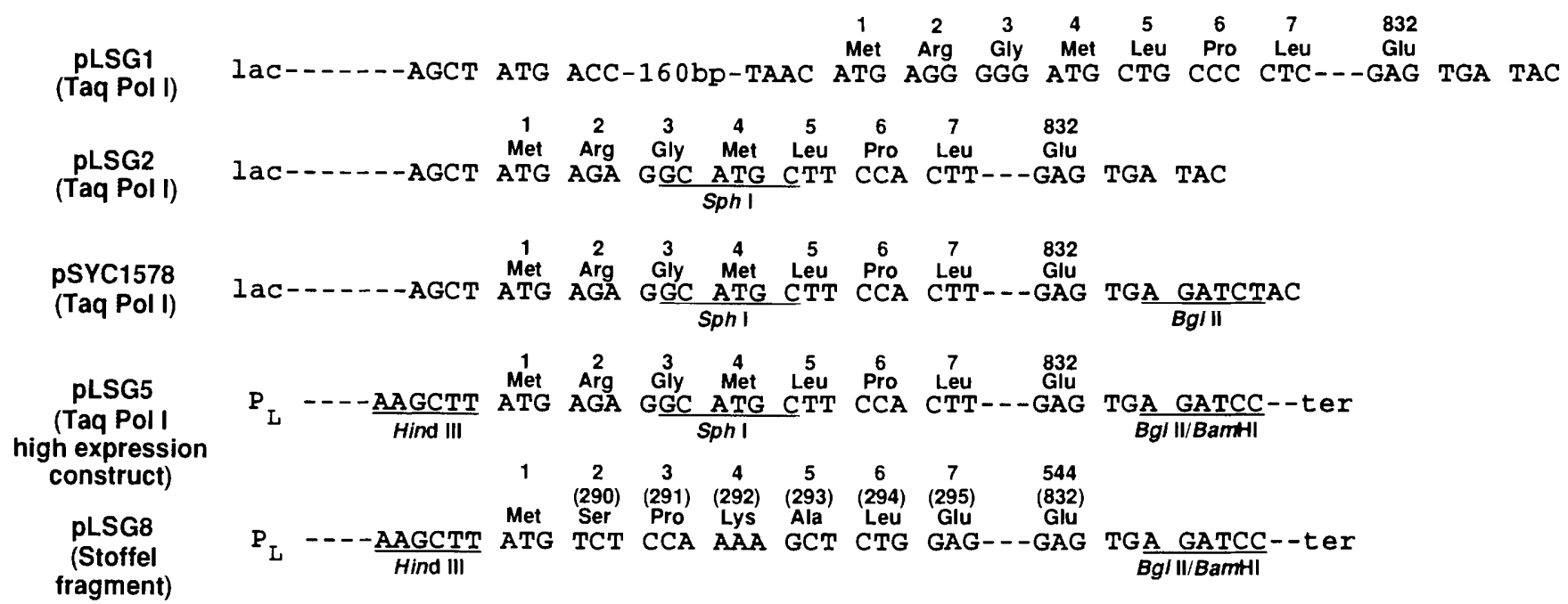

FIGURE 1 Taq Pol I expression constructions. Plasmids are described in the text. ${ }^{\text {ap }}$ Promoter-ribosome binding sites are: lac, $\beta$-galactosidase; $P_{L}, \lambda P_{L}$ promoter/gene $N$ ribosome binding site. ${ }^{b}$ Taq Pol I codons are numbered above each sequence to show the amino-terminal codons and carboxyterminal codons and how they were altered in the mutagenesis and recloning described in the text. Restriction endonuclease cleavage sites are underlined and labeled. The $B$. thuringiensis $\delta$-toxin retroregulator is indicated by ter. Numbers appearing in parentheses in pLSG8 refer to the corresponding codon numbering of the full-length gene.

duplex oligonucleotide DG29/DG30 (which provides a Met start codon as well as codons 290-293 of Taq Pol I; see Table 1). The truncated gene assembled in HindIII/BamHI-digested vector pFC54.T was designated pLSG8 (Fig. 1).

\section{Inductions}

Isopropyl- $\beta$-D-thiogalactopyranoside (IPTG)-inductions of pLSG1 and pLSG2 were as described. ${ }^{(5)}$ For heat inductions of plasmids pDG160, pLSG5, and pLSG8, cultures were inoculated to $\mathrm{OD}_{600}=$ 0.05 from a fresh $30^{\circ} \mathrm{C}$ overnight culture in Bonner-Vogel salts ${ }^{(24)}$ plus $0.25 \%$ casamino acids, $0.2 \%$ glucose, $10 \mu \mathrm{g} / \mathrm{ml}$ thiamine, and $100 \mu \mathrm{g} / \mathrm{ml}$ ampicillin. Cultures were incubated at $30^{\circ} \mathrm{C}$ until the $\mathrm{OD}_{600}$ of the culture reached 0.7 , then induced at $37^{\circ} \mathrm{C}$ or $41^{\circ} \mathrm{C}$ for $2.5-21$ $\mathrm{hr}$. For enzyme assays of small-scale inductions, frozen pellets were thawed, suspended in $50 \mathrm{~mm}$ Tris- $\mathrm{HCl}(\mathrm{pH} 7.4)$, $10 \mathrm{~mm}$ EDTA, $0.5 \mu \mathrm{g} / \mathrm{ml}$ leupeptin, 2.5 $\mathrm{mM}$ phenylmethylsulfonyl flouride (PMSF), and sonicated. Heat-treated extracts were prepared by adding $\left(\mathrm{NH}_{4}\right)_{2} \mathrm{SO}_{4}$ to $0.2 \mathrm{M}$, heating at $75^{\circ} \mathrm{C}$ for $20 \mathrm{~min}$, chilling on ice, and clarifying by centrifugation.

\section{PCR Using Heat-treated Cell Extracts}

Heat-treated extracts from $37^{\circ} \mathrm{C}$, 9-hr heat inductions of cultures of pLSG5 (Taq Pol I) and pLSG8 (Stoffel fragment) were assayed for enzyme activity. The extracts were diluted to 4 units/ $\mu$ lin $1 \times$ storage buffer $(20 \mathrm{~mm}$ Tris- $\mathrm{HCl}, \mathrm{pH} 7.5$, $100 \mathrm{~mm} \mathrm{KCl}, 0.1 \mathrm{~mm}$ EDTA, $1 \mathrm{~mm}$ dithiothreitol, $0.2 \%$ Tween 20 [Pierce, "Surfact-Amps"], and 50\% glycerol). The dilutions were used in the PCR under standard conditions $^{(3)}$ at $4,2,1,0.5$, or 0.25 units per reaction. Reactions were subjected to 30 cycles of PCR amplification using human globin gene primers, PC03 and PC04, and template DNA isolated from the human cell line Molt $4 .^{\left({ }^{(3)}\right.}$

\section{Purification of Recombinant Taq DNA Polymerase}

All operations were carried out at $0-4^{\circ} \mathrm{C}$ unless otherwise specified. All glassware was baked and all solutions were autoclaved where possible. Induced pLSG5/ DG116 cells (165 grams wet cell weight) were thawed in $165 \mathrm{ml}$ of $2 \times$ TE buffer (100 mm Tris- $\mathrm{HCl}, \mathrm{pH} 7.5,2$ mм EDTA), containing $2.4 \mathrm{~mm}$ PMSF and $0.5 \mu \mathrm{g} / \mathrm{ml}$ leupeptin, and homogenized at low speed in a blender. The thawed cells were lysed in an Aminco French Pressure Cell (20,000 psi), sonicated to reduce viscosity, and diluted to $935 \mathrm{ml}$ with $1 \times \mathrm{TE}$ containing $2.4 \mathrm{~mm}$ PMSF and $0.5 \mu \mathrm{g} / \mathrm{ml}$ leupeptin. This lysate (Fraction I; see Fig. 2A) contained 18.4 grams of protein and $45,000,000$ units of DNA polymerase activity.

Ammonium sulfate was added to 0.2 $M$ and the lysate centrifuged at $25,000 \mathrm{~g}$ for $20 \mathrm{~min}$. The supernatant, Fraction II, was incubated at $75^{\circ} \mathrm{C}$ for $15 \mathrm{~min}$ to denature $E$. coli host proteins, then cooled to $0^{\circ} \mathrm{C}$ and adjusted to $0.6 \%$ Polymin $\mathrm{P}$, precipitating approximately $90 \%$ of the $A_{260}$ absorbing material. The mixture was stirred at $0^{\circ} \mathrm{C}$ for $3 \mathrm{hr}$ and centrifuged at $25,000 \mathrm{~g}$ or $30 \mathrm{~min}$. The heatinactivation/Polymin $\mathrm{P}$ step removed $93 \%$ of the total soluble protein and yielded a greater than 14-fold purification (Fraction III, Fig. 2A).

Fraction III was loaded onto a $2.2 \times$ $11-\mathrm{cm}(42 \mathrm{ml})$ phenyl-Sepharose CL-4B (Pharmacia-LKB, Lot \#MI 02547) column (equilibrated in TE containing 0.2 $\mathrm{M}$ ammonium sulfate) at $40 \mathrm{ml} / \mathrm{hr}$. The column was washed with $400 \mathrm{ml}$ of the same buffer ( $A_{280}$ to baseline), followed by $180 \mathrm{ml}$ of TE at $50 \mathrm{ml} / \mathrm{hr}$, and finally $105 \mathrm{ml}$ of $20 \%$ (wt/vol) ethylene glycol 


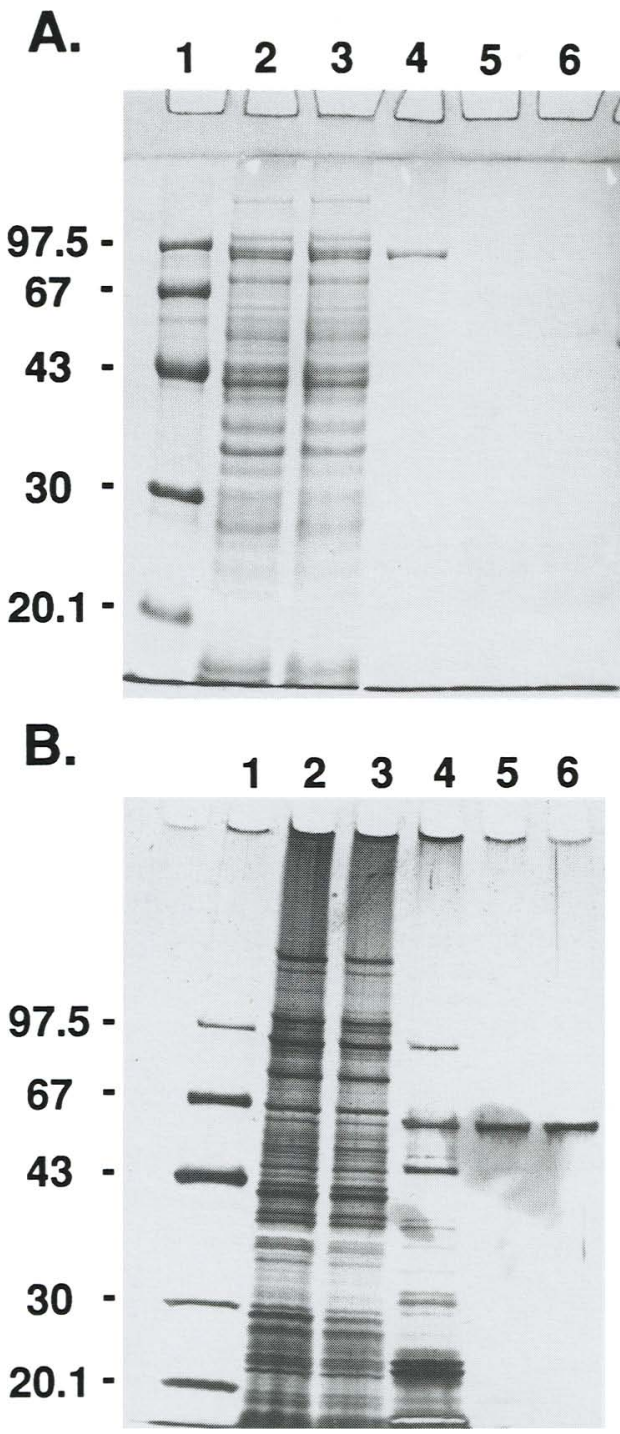

FIGURE 2 Purifications of full-length of Taq Pol I and Stoffel fragment. (A) Full-length Taq Pol I purification fractions analyzed via SDS-PAGE on a $10 \%$ running gel, $4.75 \%$ stacking gel, stained with Coomassie brilliant blue. (Lane 1) Molecular weight standard, molecular weights (in thousands) shown at left; (lane 2) $20 \mu \mathrm{g}$ of Fraction I; (lane 3) $20 \mu \mathrm{g}$ of Fraction II; (lane 4) $3 \mu \mathrm{g}$ of Fraction III; (lane 5) $3 \mu \mathrm{g}$ of early phenyl-Sepharose flow-through; (lane 6$) 3 \mu \mathrm{g}$ of late phenylSepharose flowthrough; (lane 7) $3 \mu \mathrm{g}$ of phenyl-Sepharose low-salt eluate; (lane 8) $1 \mu \mathrm{g}$ of Fraction IV; (lane 9) control from a previous purification; (lane 10) $1 \mu \mathrm{g}$ (230 units) of Fraction V. (B) Stoffel fragment purification fractions analyzed via SDS-PAGE on a 4-20\% gradient gel and stained with silver (Integrated Separation Systems). (Lane 1) Molecular weight standard, molecular weights (in thousands) shown at left; (lane 2) $1.1 \mu \mathrm{g}$ of Fraction I; (lane 3 ) $0.9 \mu \mathrm{g}$ of Fraction II; (lane 4) $2.4 \mu \mathrm{g}$ of Fraction III; (lane 5) $0.1 \mu \mathrm{g}$ of Fraction IV; (lane 6) $0.1 \mu \mathrm{g}$ (22.5 units) of Fraction V.

in $\mathrm{TE}$, removing most of the residual nucleic acid. The Taq Pol I activity was eluted with a $600-\mathrm{ml}$ linear gradient of 0-4 $\mathrm{M}$ urea in TE containing $20 \%$ ethylene glycol. Fractions $(5.5 \mathrm{ml})$ eluting between 0.25 and $2.7 \mathrm{M}$ urea were pooled forming Fraction IV (Fig. 2A), which contained $73 \%$ of the applied activity and $12 \%$ of the applied protein.
Fraction IV was loaded onto a $3.2 \times$ 9-cm (72 ml) heparin-Sepharose column (equilibrated with $100 \mathrm{~mm} \mathrm{KCl}, 50 \mathrm{~mm}$ Tris- $\mathrm{HCl}, \mathrm{pH} 7.5,0.1 \mathrm{~mm}$ EDTA, and $0.2 \%$ Tween 20) at $70 \mathrm{ml} / \mathrm{hr}$. The column was washed with $170 \mathrm{ml}$ of the same buffer containing $150 \mathrm{~mm} \mathrm{KCl}$ and eluted with a 700-ml linear gradient of $150-650 \mathrm{~mm}$ $\mathrm{KCl}$ in the same buffer. Fractions eluting between $275 \mathrm{~mm}$ and $325 \mathrm{~mm} \mathrm{KCl}$ were pooled ( $98 \mathrm{ml}$ total) and the pooled fractions concentrated/diafiltered on an Amicon YM30 membrane to a final volume of $20 \mathrm{ml}$ in a $2.5 \times$ storage buffer preparation lacking glycerol. Thirty milliliters of $80 \%$ glycerol were added to the concentrated and diafiltered sample forming Fraction $\mathrm{V}$ (Fig. 2A), which was stored at $-20^{\circ} \mathrm{C}$.

\section{Purification of 61-kD Taq Pol I, Stoffel Fragment}

Purification of the Stoffel fragment from induced pLSG8/DG116 cells proceeded as the purification of full-length Taq Pol I (above) with some modifications: Induced pLSG8/DG116 cells (15.6 grams) were homogenized and lysed (Fraction I; see Fig. 2B), as above, yielding 1.87 grams of protein and 1,046,000 units of DNA polymerase activity. Following heat treatment (Fraction II, Fig. 2B), as above, Polymin P (pH 7.5) was added slowly to $0.7 \%$. The heat-inactivation/Polymin $\mathrm{P}$ step removed $92 \%$ of the total soluble protein and yielded a greater than 14fold purification. The supernatant, Fraction IIl (Fig. 2B), was loaded onto a $1.15 \times 3.1-\mathrm{cm}(3.2 \mathrm{ml})$ phenyl-Sepharose column at $10 \mathrm{ml} / \mathrm{hr}$. All of the applied activity was retained on the column. The column was washed with $15 \mathrm{ml}$ of the equilibration buffer and then with $5 \mathrm{ml}$ of $100 \mathrm{~mm} \mathrm{KCl}$ in $50 \mathrm{~mm}$ Tris- $\mathrm{HCl}(\mathrm{pH}$ 7.5), 1 mM EDTA (TE). The polymerase activity was eluted with $2 \mathrm{M}$ urea in TE containing $20 \%$ ethylene glycol. Fractions $(0.5 \mathrm{ml}$ each) with polymerase activity were pooled $(8.5 \mathrm{ml})$ and dialyzed into heparin sepharose buffer containing $100 \mathrm{mM} \mathrm{KCl}$, forming Fraction IV (Fig. 2B). This fraction contained $87 \%$ of the applied activity and $3.6 \%$ of the applied protein, yielding a 24 -fold purification. Fraction IV was loaded onto a 1.0$\mathrm{ml}$ bed volume heparin-Sepharose column equilibrated as above. The column was washed with $6 \mathrm{ml}$ of the same buffer ( $A_{280}$ to baseline) and eluted with a $15-\mathrm{ml}$ linear gradient of $100-500 \mathrm{~mm}$ $\mathrm{KCl}$ in the same buffer. Fractions $(0.15$ $\mathrm{ml}$ ) eluting between 165 and $255 \mathrm{~mm}$ $\mathrm{KCl}$ were pooled $(2.5 \mathrm{ml})$ and diafiltered on a Centricon 30 membrane into a $2.5 \times$ storage buffer preparation lacking glycerol, forming Fraction V (Fig. 2B).

\section{Enzyme Purification Activity Assays}

DNA polymerase assays were performed 
in a $50-\mu$ l volume at $75^{\circ} \mathrm{C}$ essentially as described. ${ }^{(5)}$ For full-length Taq Pol I, assay conditions were $25 \mathrm{~mm}$ $\mathrm{N}$-tris[hydroxymethyl]methyl-3-aminopropanesulfonic acid (TAPS) (pH 9.5), 1 mM $\beta$-mercaptoethanol, $2 \mathrm{mM} \mathrm{MgCl}_{2}, 50$ $\mathrm{mM} \mathrm{KCl}, 200 \mu \mathrm{M}$ each dATP, TTP, and dGTP, $100 \mu \mathrm{M}\left[\alpha_{-}{ }^{32} \mathrm{P}\right] \mathrm{dCTP}(0.05 \mathrm{Ci} /$ mmole), and $250 \mu \mathrm{g} / \mathrm{ml}$ activated salmon sperm DNA template. For the Stoffel fragment, assay conditions at $75^{\circ} \mathrm{C}$ were $25 \mathrm{~mm}$ Tris- $\mathrm{HCl}(\mathrm{pH} \mathrm{8.3)}, 1 \mathrm{~mm}$ $\beta$-mercaptoethanol, $4 \mathrm{~mm} \mathrm{MgCl}, 15 \mathrm{~mm}$ $\mathrm{KCl}, 200 \mu \mathrm{M}$ each dATP, TTP, and dGTP, $100 \mu \mathrm{M}\left[\alpha{ }^{32} \mathrm{P}\right] \mathrm{dCTP}(0.1-0.2 \mathrm{Ci} / \mathrm{mmole})$, and $250 \mu \mathrm{g} / \mathrm{ml}$ of activated salmon sperm DNA template.

\section{Divalent Metal Ion Optimization}

A Titrisol standard solution of $\mathrm{MgCl}_{2}$ (VWR Scientific) was used to titrate a solution of EDTA colorimetrically. ${ }^{(25)}$ The EDTA was then used to determine the actual concentration of previously prepared stocks of $\mathrm{MgCl}_{2}, \mathrm{MnCl}_{2}, \mathrm{CoCl}_{2}$, and $\mathrm{NiCl}_{2}$. All optimization assays used activated salmon sperm DNA template $(250 \mu \mathrm{g} / \mathrm{ml})$. Optimizations were performed in $25 \mathrm{~mm}$ Tris- $\mathrm{HCl}(\mathrm{pH} 8.3)$ (25 mm TAPS, pH 9.4, for Taq Pol I $\mathrm{MgCl}_{2}$ optimizations), $55 \mathrm{~mm} \mathrm{KCl}$, and 11.2 fmoles polymerase $(21 \mathrm{ng} / \mathrm{ml}$ for Taq Pol I and $13.6 \mathrm{ng} / \mathrm{ml}$ for the Stoffel fragment) per reaction, in otherwise standard $50-\mu$ l assays. ${ }^{(5)}$

\section{KCl Optimization}

Optimization reactions $(50 \mu \mathrm{l})$ for $\mathrm{KCl}$ concentration with Taq Pol I (11.2 fmoles enzyme; $21 \mathrm{ng} / \mathrm{ml}$ ) using both the M13 primer-template (53 $\mathrm{nm}$ ) and activated DNA template $(250 \mu \mathrm{g} / \mathrm{ml})$ contained $2.5 \mathrm{mM} \mathrm{MgCl}_{2}$ in an otherwise standard TAPS, pH 9.4 buffer. $^{(5)}$ For $\mathrm{KCl}$ optimization in assays using the Stoffel fragment, activated DNA template (250 $\mu \mathrm{g} / \mathrm{ml}$ ) assays $(50 \mu \mathrm{l})$ were performed in $25 \mathrm{~mm}$ Tris- $\mathrm{HCl}$ ( $\mathrm{pH} 8.3$ ), $4 \mathrm{~mm} \mathrm{MgCl}_{2}$ with 11.2 fmoles enzyme (13.7 $\mathrm{ng} / \mathrm{ml})$, whereas M13 primer-template (53 nM) assays $(50 \mu \mathrm{l})$ were performed in $25 \mathrm{~mm}$ Tris- $\mathrm{HCl}(\mathrm{pH} 8.3), 4.5 \mathrm{~mm} \mathrm{MgCl}_{2}$ with 27.9 fmoles polymerase $(34 \mathrm{ng} / \mathrm{ml}) . \mathrm{KCl}$ concentration was varied from 0 to 200 mM.

\section{Thermal Activity Profile Assay}

Taq Pol I thermal activity assay condi- tions were either $2 \mathrm{mM} \mathrm{MgCl}_{2}, 12$ fmoles polymerase $(22.5 \mathrm{ng} / \mathrm{ml})$, and $250 \mu \mathrm{g} / \mathrm{ml}$ activated template or $3 \mathrm{~mm} \mathrm{MgCl}_{2}, 74.4$ fmoles polymerase $(140 \mathrm{ng} / \mathrm{ml})$, and 60 nM primer-template, in an otherwise standard 50- $\mu$ l TAPS, pH 9.4 reaction. Assay conditions of the thermal activity of the Stoffel fragment were $25 \mathrm{~mm}$ Tris$\mathrm{HCl}(\mathrm{pH} \mathrm{8.3),} 25 \mathrm{~mm} \mathrm{KCl}$, and either 4.0 $\mathrm{mM} \mathrm{MgCl}, 11.2$ fmoles polymerase (13.7 $\mathrm{ng} / \mathrm{ml}$ ), and $250 \mu \mathrm{g} / \mathrm{ml}$ activated DNA template or $4.5 \mathrm{~mm} \mathrm{MgCl}_{2}, 74.4$ fmoles polymerase $(90.8 \mathrm{ng} / \mathrm{ml})$, and $60 \mathrm{~nm}$ primer-template.

\section{Thermal Inactivation Assay}

Thermal inactivation assays of Taq Pol I and Stoffel fragment were carried out in a standard PCR mixture: $10 \mathrm{~mm}$ Tris- $\mathrm{HCl}$ (pH 8.3), $0.5 \mathrm{ng} \lambda$ DNA template, $200 \mu \mathrm{M}$ each of dATP, TTP, and dGTP, $0.2 \mu \mathrm{M}$ each of two oligonucleotide primers, and either $50 \mathrm{~mm} \mathrm{KCl,} 2 \mathrm{~mm} \mathrm{MgCl}$, and 1.25 units $(4.3 \mathrm{ng})$ of Taq Pol I or $10 \mathrm{~mm}$ $\mathrm{KCl}, 3 \mathrm{mM}^{\mathrm{MgCl}_{2}}$, and 5 units (13.5 $\mathrm{ng}$ ) of Stoffel fragment in a $50-\mu$ l reaction volume. Reaction mixtures were overlaid with paraffin oil and incubated at either $95^{\circ} \mathrm{C}$ or $97.5^{\circ} \mathrm{C}$ for $0,2,5,10,30$, or 60 min. Aliquots $(5 \mu \mathrm{l})$ were held on ice until assayed in the presence of $100 \mu \mathrm{M}$ $\left[\alpha^{32} \mathrm{P}\right] \mathrm{dCTP}$ for polymerase enzyme activity on activated salmon sperm DNA in the enzyme purification activity assay described above.

\section{5' to 3' Exonuclease Activity Assay}

Five picomoles of $5^{\prime}{ }^{32}$ P-labeled, $3^{\prime}$ phosphorylated oligonucleotide DG67 (Table 1) was annealed to 6 pmoles of single-stranded TSYC657 DNA in the presence (to form a 133-nucleotide gap between the $3^{\prime}$ end of DG48 and the 5' end of DG67) or absence of 15 pmoles of the synthetic oligonucleotide primer DG48 (Table 1) in a $60-\mu$ l reaction containing $10 \mathrm{~mm}$ Tris- $\mathrm{HCl}$ ( $\mathrm{pH} \mathrm{8.3),} 50 \mathrm{~mm}$ $\mathrm{KCl}$, and $0.1 \mathrm{~mm}$ EDTA. The annealing mixture was heated to $95^{\circ} \mathrm{C}$ for $4 \mathrm{~min}$, incubated at $70^{\circ} \mathrm{C}$ for $10 \mathrm{~min}$, and then cooled to room temperature. Exonuclease activity was assayed at $70^{\circ} \mathrm{C}$ for 6 min in a $30-\mu l$ reaction containing $1 \mathrm{~mm}$ $\beta$-mercaptoethanol, $25 \mathrm{~mm}$ TAPS $(\mathrm{pH}$ 9.4), $50 \mathrm{~mm} \mathrm{KCl}, 2 \mathrm{mM} \mathrm{MgCl}_{2}, 200 \mu \mathrm{M}$ each TTP, dATP, dGTP, and dCTP, $6 \mu \mathrm{l}$ (0.6 pmole single-strand DNA) of the above annealing mixture, and either 0.05 pmole $(157 \mathrm{ng} / \mathrm{ml})$ or 1 pmole $(3.1$ $\mu \mathrm{g} / \mathrm{ml})$ of Taq Pol I, or 2 pmoles $(4.1 \mu \mathrm{g} /$ $\mathrm{ml}$ ) of Stoffel fragment. Reactions were stopped by the addition of $6 \mu \mathrm{l}$ of $60 \mathrm{~mm}$ EDTA. The reaction products were fractionated electrophoretically on a $20 \%$ polyacrylamide gel and analyzed by autoradiography. Radioactivity was quantitated by liquid scintillation spectrometry of excised reaction products.

\section{RESULTS}

\section{DNA Sequence Manipulations}

Figure 1 shows a summary of the plasmids described below and the pertinent DNA sequence changes among them. As previously described, ${ }^{(5)}$ plasmid pLSG1 contains the full-length Taq Pol I gene under transcriptional control of the $E$. coli lac promoter. IPTG-induced cultures harboring PLSG1 produce 14-37 units of Taq Pol I per milligram of total crude extract protein (Table 2 and ref. 5) or $\sim 0.005-0.015 \%$ of total protein. To increase expression levels of Taq Pol I, several manipulations were performed. Oligonucleotide mutagenesis of the $5^{\prime}$ end of the gene resulted in a 170-bp deletion of Taq and vector DNA, moving the ATG of Taq Pol I into the position of the ATG codon of $\beta$-galactosidase. In addition, a SphI site (in italics, below) was introduced near the Taq Pol I ATG start codon by changing a $G$ to a $C$ in the third codon. Also, codons two, five, six, and seven were altered in their third positions to be more AT rich, changing the DNA sequence from ATG AGG GGG ATG CTG CCC CTC to ATG AGA GGC ATG CTT CCA CTT without altering the amino acid sequence of the translated protein. The resulting plasmid was designated pLSG2. An IPTG-induced pLSG2 culture has Taq Pol I activity of 639 units/mg crude extract protein, a 38-fold increase over an uninduced culture (Table 2). The $3^{\prime}$ end of the Taq Pol I gene in pLSG2 was mutagenized to introduce a BglII site (in italics, below) at the stop codon, changing that sequence from TGATAC to TGAGATCTAC. The resulting plasmid, with the Taq Pol I gene altered at both the $5^{\prime}$ and $3^{\prime}$ ends was designated pSYC1578.

\section{Cloning and Expression of Taq Pol I in $P_{L}$ Expression Vector}

The plasmid expression vector into which we cloned the Taq Pol I gene uti- 
TABLE 2 Taq Polymerase Activity in E. coli Extracts

\begin{tabular}{llcc}
\hline Experiment & Extract & Uninduced $^{\mathrm{a}}(-) /$ Induced $(+)$ & Specific activity $^{\mathrm{b}}$ \\
\hline I & pDG160 & + & $\leqslant 0.06^{\mathrm{c}}$ \\
& pLSG1 & - & 1.1 \\
& pLSG2 & + & 14.3 \\
& + & 16.7 \\
& pLSG5 & - & 639 \\
& & $+\left(37^{\circ} \mathrm{C}\right)$ & 97.6 \\
& & $+\left(41^{\circ} \mathrm{C}\right)$ & 2790 \\
II & + & 362.7 \\
& pDG160 & $-\left(5 \mathrm{hr}, 30^{\circ} \mathrm{C}\right)$ & 50.07 \\
& pLSG8 & $+\left(5 \mathrm{hr}, 37^{\circ} \mathrm{C}\right)$ & 61.9 \\
& & $+\left(5 \mathrm{hr}, 41^{\circ} \mathrm{C}\right)$ & 1037.4 \\
& $-\left(21 \mathrm{hr}, 30^{\circ} \mathrm{C}\right)$ & 3163.7 \\
& & $+\left(21 \mathrm{hr}, 37^{\circ} \mathrm{C}\right)$ & 506.7 \\
& & $+\left(21 \mathrm{hr}, 41^{\circ} \mathrm{C}\right)$ & 9503.4 \\
& & $12,310.1$ \\
\hline
\end{tabular}

${ }^{a}$ Experiment I: pDG160 and pLSG5 were heat-induced as described in Materials and Methods for $9 \mathrm{hr}$. Experiment II: pDG160 and pLSG8 heat inductions were 5 or $21 \mathrm{hr}$. Uninduced cultures were incubated at $30^{\circ} \mathrm{C}$ for the same amount of time. IPTG induction of pLSG1 and pLSG2 is also described in Materials and Methods.

${ }^{b}$ Specific activity in units/mg total crude extract protein when assayed, as described ${ }^{(5)}$ on clarified, heat-treated extract, for Experiment I and as described in Materials and Methods for Experiment II.

${ }^{\mathrm{C}} \mathrm{A}$ background of $0.01 \%$ input counts has been subtracted. The specific activity represents less than two times background.

lizes the bacteriophage $\lambda \mathrm{P}_{\mathbf{L}}$ promoter and gene $N$ ribosome binding site. The Taq Pol I cloning preserved the natural spacing between the gene $N$ ribosome binding site and ATG start codon. In addition, the vector provides the Bacillus thuringiensis positive retroregulator and point mutations in RNA II, rendering the plasmid temperature sensitive for copy number as described. ${ }^{(12)}$ A culture harboring pLSG5 was heat-induced, as described in Materials and Methods. Taq Pol I activity in a heat-treated crude extract of induced pLSG5 was approximately four-fold higher than in pLSG2 (Table 2). A corresponding increase in induced Taq Pol I protein was also seen upon SDS-PAGE analysis (data not shown).

Others have observed ${ }^{(26,27)}$ that proteins produced upon heat induction of $\mathrm{P}_{\mathrm{L}}$ promoter constructs at $42^{\circ} \mathrm{C}$ are insoluble. By lowering the induction temperature to $37^{\circ} \mathrm{C}$ or $41^{\circ} \mathrm{C}$, these investigators found they could increase the solubility of induced proteins significantly. We compared heat-treated crude extracts of pLSG5 that had been induced at $37^{\circ} \mathrm{C}$ or $41^{\circ} \mathrm{C}$. Enzyme assays show that we recovered 8- to 13-fold less DNA polymerase activity in the heat-treated extract from the $41^{\circ} \mathrm{C}$ induction compared to that from the $37^{\circ} \mathrm{C}$ induction (Table 2 ). In addition, we observed more degraded forms of Taq Pol I in a Western blot of total protein from the $41^{\circ} \mathrm{C}$-induced culture compared to that from the $37^{\circ} \mathrm{C}$-in duced culture (data not shown). Based on the specific activity of the polymerase and protein determination on total crude lysate, the induced activity in the pLSG5/DG116 culture at $37^{\circ} \mathrm{C}$ represented $1-2 \%$ of total protein being expressed as Taq Pol I.

\section{Cloning and Expression of Truncated Taq Pol I}

We had observed immunoreactivity and enzymatic activity in induced cultures harboring pFC84 and pFC85, which were deleted for the first 615 nucleotides of the Taq Pol I gene. ${ }^{(5)}$ Thus, there was reason to believe that other truncated forms of Taq Pol I could be active. The BstXI recognition site in the Taq Pol I gene at nucleotide 872 (amino acid 291) is directly upstream of the region corresponding to the end of $E$. coli Pol I small fragment. In addition, the BstXI recognition site is approximately 570 bp (190 amino acids) proximal to the beginning of the region that, when translated, shows high amino acid similarity to the polymerase domain of $E$. coli Pol I. Because the $E$. coli Pol I Klenow fragment is active as a polymerase, we made a deletion of Taq Pol I that we hoped would express a thermostable polymerase molecule analogous to Klenow fragment.

Unlike its full-length counterpart, the Stoffel fragment activity is not lost upon heat-induction at $41^{\circ} \mathrm{C}$ (Table 2). After 21 hr at $41^{\circ} \mathrm{C}$, a heat-treated crude extract from a culture harboring pLSG8 had 12,310 units of heat-stable DNA polymerase activity per milligram of crude extract protein, a 24-fold increase over an uninduced culture. A heat-treated extract from a $21-\mathrm{hr}, 37^{\circ} \mathrm{C}$-induced pLSG8 culture had 9503 units of activity per milligram of crude extract protein. Table 2 shows the difference in accumulated levels of polymerase activity between 5 hr and $21 \mathrm{hr}$ of induction - a ninefold increase between $5 \mathrm{hr}$ and $21 \mathrm{hr}$ at $37^{\circ} \mathrm{C}$ and a nearly fourfold increase between 5 hr and 21 hr at $41^{\circ} \mathrm{C}$.

\section{Activity of Crude Extracts in PCR}

To determine whether both the fulllength and Stoffel fragment forms of Taq Pol I (encoded by pLSG5 and pLSG8, respectively) were active in PCR, we performed PCR assays using heat-treated crude extracts from induced cultures of pLSG5 and pLSG8. Heat-treated extracts containing approximately $4,2,1,0.5$, or 0.25 units of enzyme activity were used in otherwise standard PCR amplifications. ${ }^{(3)}$ The results, shown in Figure 3, indicated that both the full-length (lanes 1-5) and Stoffel fragment (lanes 7-11) Taq Pol I enzymes were thermostable and functioned well in PCR. The fulllength enzyme functioned well in PCR at 0.5-2 units of enzyme. Faint PCR products were visible from reactions carried out with 0.25 unit of enzyme. Four units of enzyme in the reactions yielded highmolecular-weight nonspecific products, as expected. ${ }^{(28)}$ In contrast, PCR product was only observed in the reactions utilizing 4 units and 2 units of Stoffel fragment (lanes 7 and 8). Interestingly, a significantly higher yield of intended specific product was obtained with 4 units of Stoffel fragment. In addition, nonspecific higher-molecular-weight products were not visible.

\section{Enzyme Purification}

The purification of full-length Taq DNA 


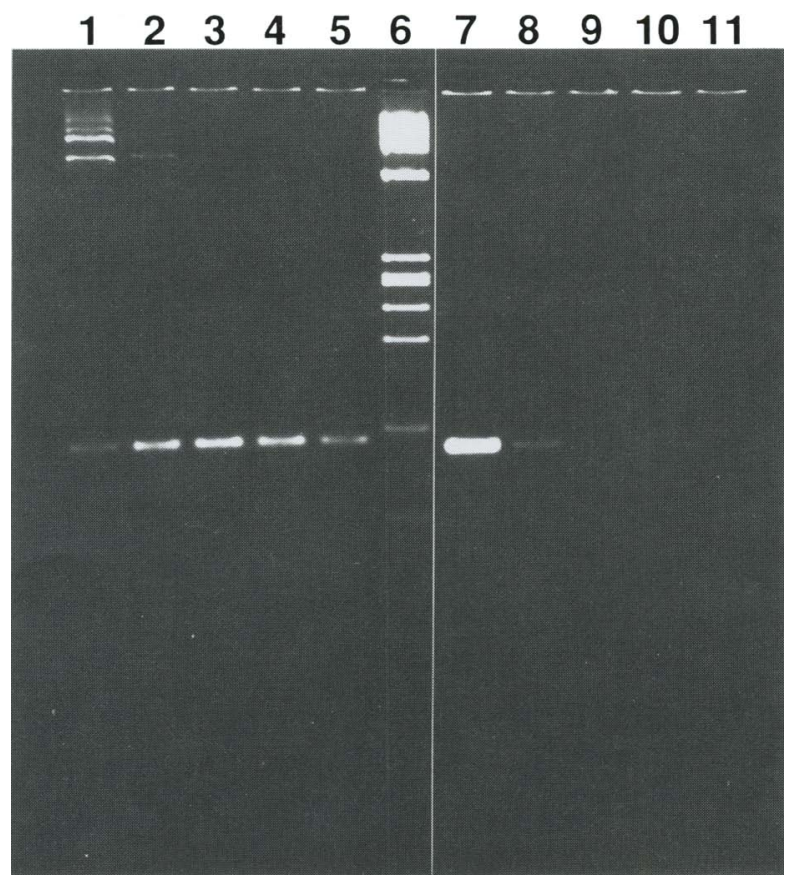

FIGURE 3 PCR comparing the two forms of Taq Pol l. PCR using heat-treated extracts of induced cultures is described in Materials and Methods. (Lanes 1-5) Taq Pol I from pLSG5; (lanes 7-11) Stoffel fragment from pLSG8; (lane 6) molecular weight marker; (lanes 1 and 7 ) 4 units of enzyme; (lanes 2 and 8) 2 units; (lanes 3 and 9) 1 unit; (lanes 4 and 10) 0.5 units; (lanes 5 and 11) 0.25 units.

polymerase (Fraction V, Fig. 2A) resulted in the recovery of $32,600,000$ units $(73 \%)$ of polymerase activity. Between $11 \mathrm{mg}$ (protein concentration determined by amino acid composition) and $14 \mathrm{mg}$ (protein concentration determined by Lowry assay using BSA as a standard) of protein were obtained, resulting in a calculated specific activity between 230,000 and 290,000 units/mg protein, and representing a $97-$ to 122 fold purification. The predicted molecular weight of Taq Pol I (based on the determined DNA sequence of the 832codon open reading frame) is 93,920 daltons. A specific activity of 290,000 units/mg protein yields a calculated molecular turnover number of 150 nucleotides per second at $75^{\circ} \mathrm{C}$.

The purification of the Stoffel fragment (Fraction V, Fig. 2B) yielded $1,291,588$ units of DNA polymerase activity and $2.8 \mathrm{mg}$ of protein. The calculated specific activity of the Stoffel fragment is 369,000 units/mg protein, representing a 451-fold purification. The predicted molecular weight of the Stoffel fragment (based on the determined DNA sequence of the 543- or 544- codon open reading frame, see below) is $61.3 \mathrm{kD}$, yielding a calculated molecular turnover number of 130 nucleotides per second at $75^{\circ} \mathrm{C}$. For comparison, the specific activity of $E$. coli DNA polymerase I Klenow Fragment is between 8,000 and 30,000 units/mg, ${ }^{(29-31)}$ and the specific activity of T7 DNA polymerase (T7 gene 5 protein and $E$. coli thioredoxin) is $10,000-$ 55,000 units/mg. ${ }^{(29,32)}$ The ranges are a reflection of the dependence of the enzyme activity on the nature of the DNA substrate in the assay.

Based on amino acid analysis (data not shown), recombinant Taq Pol I (in contrast to native Taq DNA Polymerase) was not blocked at the amino terminus and retained the initiating methionine residue, as would be predicted from the properties of $E$. coli methionine amino peptidase. ${ }^{(33)}$ Amino acid analysis of the purified Stoffel fragment yielded a complex result. The expected amino acid sequence at the amino terminus of the protein is Met-Ser-Pro-Lys-Ala. Unlike Taq Pol I, the majority of the purified Stoffel fragment did not retain the initiating methionine residue. The amino terminus of the major species was SerPro-Lys-Ala. However, there were two minor species in the analysis, one of which had the amino-terminal Met, the other of which had a Pro at its amino terminus.

\section{Optimization Studies}

Figure 4 shows divalent metal ion titration data for Taq Pol I (A) and Stoffel fragment (B) enzymes using $\mathrm{MgCl}_{2}$, $\mathrm{MnCl}_{2}$, and $\mathrm{CoCl}_{2}$. Assays using $\mathrm{NiCl}_{2}$ yielded little, if any, detectable polymerase activity for either enzyme (data not shown). For Taq Pol I, magnesium chloride stimulated enzyme activity maximally at 2-3 mm (Fig. 4A) and 10 $\mathrm{mM} \mathrm{MgCl}_{2}$ yielded only $60 \%$ of the maximum activity, at $200 \mu \mathrm{M}$ each TTP, $\mathrm{dATP}$, and dGTP and $100 \mu \mathrm{M}$ dCTP. Maximal stimulation of activity with $\mathrm{MnCl}_{2}$ $(0.6 \mathrm{~mm})$ and $\mathrm{CoCl}_{2}(0.6 \mathrm{~mm})$ was approximately $80 \%$ of the maximal activity stimulated by $\mathrm{MgCl}_{2}$. Similar to Taq Pol $\mathrm{I}$, the Stoffel fragment showed a prefer-

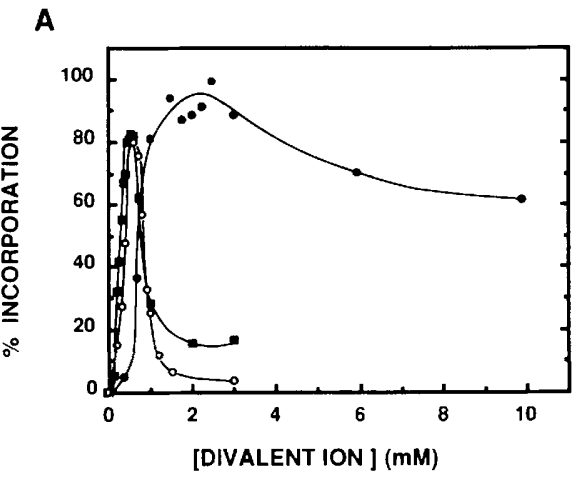

B

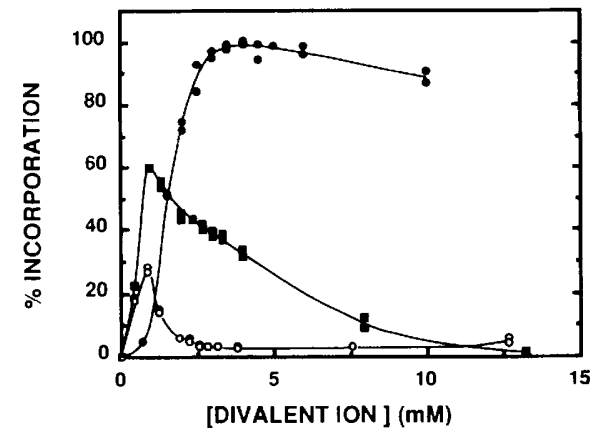

FIGURE 4 Divalent metal ion titration. The influence of $\mathrm{MgCl}_{2}(\mathbf{O}), \mathrm{MnCl}_{2}(\mathbf{\square})$, and $\mathrm{CoCl}_{2}(O)$ on Taq Pol $\mathrm{I}(A)$, and Stoffel fragment $(B)$ enzyme activities. Assays and titration are as described in Materials and Methods and results are plotted as the percent of maximum dCMP incorporation with respect to increasing concentration of divalent metal ion. 
ence for $\mathrm{MgCl}_{2}$. Unlike the full-length form, Stoffel fragment enzyme activity was maximally stimulated over a broad concentration range of $\mathrm{MgCl}_{2}$, with a maximum of $4 \mathrm{~mm}$ (Fig. 4B). Similarly, Stoffel fragment activity was stimulated over a broad concentration range of $\mathrm{MnCl}_{2}$, with a maximum of $0.92 \mathrm{~mm}$ (60\% of the maximal activity achieved with $\mathrm{MgCl}_{2}$ ). Cobalt chloride stimulated Stoffel fragment activity maximally at $0.88 \mathrm{~mm}(27 \%$ of the maximal activity achieved with $\mathrm{MgCl}_{2}$ ).

Figure 5 shows that the influence of $\mathrm{KCl}$ concentration differs between Taq Pol I and the Stoffel fragment and also depends on the template used in the assay. For Taq Pol I assayed with activated DNA template, the optimum $\mathrm{KCl}$ concentration was $55 \mathrm{~mm}$ with approxi-

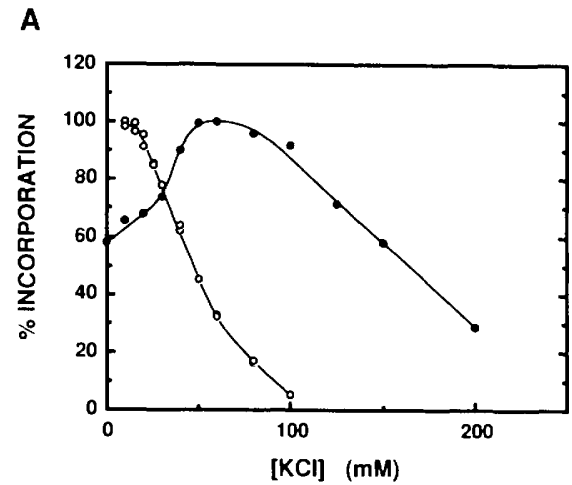

B

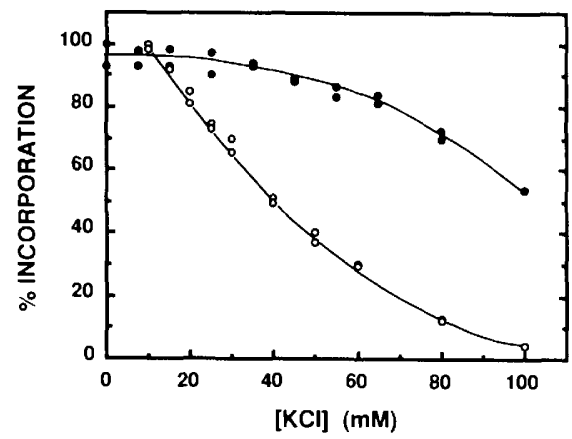

FIGURE $5 \mathrm{KCl}$ titration. The influence of $\mathrm{KCl}$ on Taq Pol $\mathrm{I},(A)$ and Stoffel fragment $(B)$ enzyme activities using either activated salmon sperm DNA template (O) or the defined M13 primer-template $(O)$, as described in Materials and Methods. One-hundred percent incorporation represents 155 pmoles of dCMP incorporated for Taq Pol I with the activated template, 106 pmoles for Taq Pol I with the M13 primer-template, 110 pmoles for Stoffel fragment with the activated template, and 92 pmoles for Stoffel fragment with the M13 primer-template. mately $58 \%$ activity at 0 and $150 \mathrm{~mm}$. In contrast, with Taq Pol I and the M13 primer-template, maximum activity was achieved at $10 \mathrm{~mm} \mathrm{KCl}$ (activity in the absence of $\mathrm{KCl}$ was not determined) with $48 \%$ activity at $50 \mathrm{mM} \mathrm{KCl}$. For the Stoffel fragment with activated DNA template, maximum activity was achieved with 0 $\mathrm{KCl}$, although polymerase activity remained above $90 \%$ of maximum up to $45 \mathrm{~mm} \mathrm{KCl}$ and remained over $50 \%$ at $100 \mathrm{~mm} \mathrm{KCl}$. In contrast, with $\mathrm{M} 13$ primer-template and the Stoffel fragment, activity declined rapidly at greater than $10 \mathrm{~mm} \mathrm{KCl}$. Assaying the M13 primer-template with $40 \mathrm{~mm} \mathrm{KCl}$ yielded approximately $50 \%$ maximum activity and activity declined to near 0 by 100 $\mathrm{mm} \mathrm{KCl}$.

\section{Thermoactivity and Thermal Inactivation}

Thermal activity profiles of Taq Pol I and the Stoffel fragment on M13 primer-template and activated salmon sperm DNA were compared. Figure 6 shows that the optimal temperature depends on the nature of the DNA template. DNA polymerase activity increased faster, initially, with increasing temperature on the M13 primer-template than on the activated DNA. For both forms of the enzyme, the primer-template substrate is primarily single-stranded DNA (approximately 390 $\mu \mathrm{M}$ total single-stranded template nucleotide and 53 nм primer duplex). In contrast, the activated DNA (approximately $750 \mu \mathrm{M}$ total DNA nucleotide) substrate is primarily duplex DNA containing an undefined, but probably high, concentration of nicks and short gaps. ${ }^{(17)}$ The pronounced difference in thermal activity with inherently different substrates could reflect differences either in DNA binding constants or stability constants for single-stranded or double-stranded DNA as a function of temperature. Alternatively, the relative increase in activity on M13 primer-template DNA at $65^{\circ} \mathrm{C}$ and lower may accurately reflect the difference in extension rate for the polymerase when there is no blocking strand. If the extension rate is limited by the presence of a blocking strand (e.g., limited 5' to 3' exonuclease activity during synthesis or limited ability to catalyze strand-displacement synthesis), the sharp and pronounced transition in ac-
A

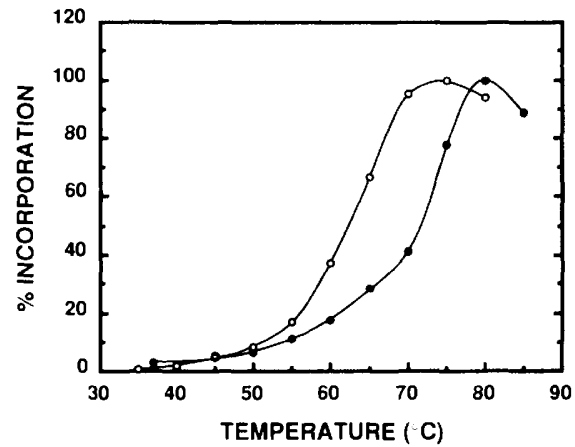

B

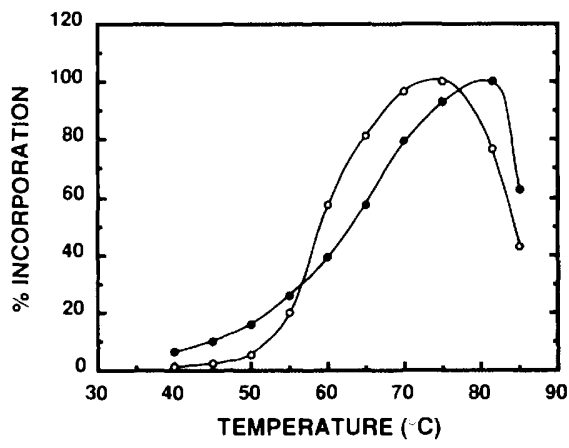

FIGURE 6 Thermal activity profiles of purified recombinant Taq DNA polymerases. Activity is represented as percent of maximum dCMP incorporation for each template and enzyme (assays performed under previously determined optimum conditions). (A) Taq Pol I with: $(O)$ activated template ( $100 \%$ represents 114 pmoles of dCMP incorporated); (O) M13 primer-template $(100 \%$ represents 80 pmoles of dCMP incorporated). (B) Stoffel fragment with: (O) activated template ( $100 \%$ represents 150 pmoles of dCMP incorporated); $(O) \mathrm{M} 13$ primer-template ( $100 \%$ represents 130 pmoles of dCMP incorporated).

tivity on salmon sperm DNA at $70-75^{\circ} \mathrm{C}$ could reflect denaturation of the template blocking strand.

Figure 7 shows the steady-state thermal inactivation of recombinant Taq Pol $I$ and the Stoffel fragment at $95^{\circ} \mathrm{C}$ and $97.5^{\circ} \mathrm{C}$ under PCR buffer conditions. Taq Pol I has an activity half-life of approximately $45-50 \mathrm{~min}$ at $95^{\circ} \mathrm{C}$, and $9 \mathrm{~min}$ at $97.5^{\circ} \mathrm{C}$. Native Taq Pol I was inactivated with similar kinetics (data not shown). The half-life of the Stoffel fragment at $97.5^{\circ} \mathrm{C}$ is approximately $21 \mathrm{~min}$. The thermal inactivation of the Stoffel fragment was unaffected by $\mathrm{KCl}$ concentration over a range of $0-50 \mathrm{~mm}$ (data not shown). These results do not measure thermoresistance of the enzymes in ther- 


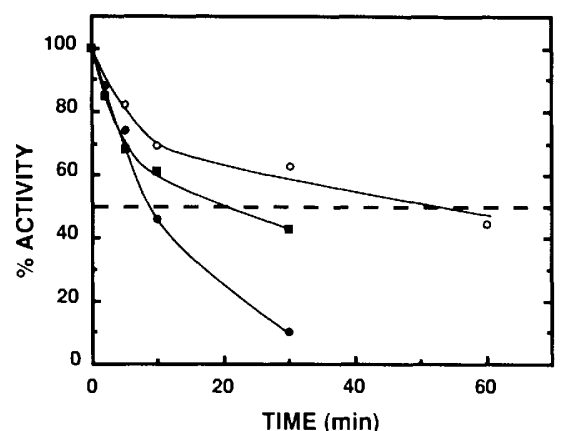

FIGURE 7 Thermoresistance of purified recombinant Taq DNA polymerases. Percent remaining enzyme activity as a function of time. (O) Taq Pol I, $97.5^{\circ} \mathrm{C}$; (O) Taq Pol I, $95^{\circ} \mathrm{C}$; (ם) Stoffel fragment, $97.5^{\circ} \mathrm{C}$. The intersection of each solid line with the dashed line indicates the approximate $t^{1 / 2}$ for each condition.

mal cycling or otherwise repeated short exposure to high temperatures.

\section{$5^{\prime}$ to $3^{\prime}$ Exonuclease Activity}

The ability of Taq Pol I and the Stoffel fragment to excise 5 '-terminal nucleotides from a variety of DNA substrates was examined (Table 3). The 5' to 3' exonuclease activity of Taq Pol I was negligible on single-stranded DNA, i.e., a 5'-

TABLE $35^{\prime}$ to $3^{\prime}$ Exonuclease Activity

\begin{tabular}{llc}
\hline Enzyme & Substrate & $\begin{array}{c}\text { Percent } \\
\text { release }^{\mathrm{a}}\end{array}$ \\
\hline Taq Pol I & & \\
(0.05 pmole) & ss DNA $^{\mathrm{b}}$ & 1.7 \\
& ds DNA $^{\mathrm{c}}$ & $\mathrm{ND}$ \\
& ds DNA & \\
& \multicolumn{1}{c}{ with primer $^{\mathrm{d}}$} & 64.4 \\
& & \\
Taq Pol I & & 6.4 \\
(1 pmole) & ss & 18.0 \\
& ds & 77.6 \\
Stoffel fragment & ds with primer & \\
(2 pmoles) & ss & ND \\
& ds & ND \\
& ds with primer & 0.5 \\
\hline
\end{tabular}

${ }^{\text {a}}$ Release is percent of $5^{\prime}$-terminal nucleotides converted to mono- or dinucleotides, quantitated by liquid scintillation spectrometry of excised reaction products previously separated via PAGE.

boligonucleotide DG67, ${ }^{32}$ P-phosphorylated at its $5^{\prime}$ end.

'DG67 (above) annealed with TSYC657.

dTSYC657/DG67 complex (above) additionally annealed with upstream DG48. phosphorylated oligonucleotide. The activity was moderate on the $5^{\prime}$-phosphorylated recessed end of doublestranded DNA, which was a 5'-phosphorylated oligonucleotide annealed to single-stranded circular DNA in this assay. It is only in the presence of an upstream primer that the enzyme possessed substantial $5^{\prime}$ to $3^{\prime}$ exonuclease activity, yielding $78 \%$ release of $5^{\prime}$ nucleotides compared to $18 \%$ in the absence of a competent upstream primer. Thus, this activity is a polymerization-dependent $5^{\prime}$ to $3^{\prime}$ exonuclease. In contrast, as predicted from the amino acid sequence, the Stoffel fragment was completely devoid of exonuclease activity (Table 3 ).

\section{DISCUSSION}

DNA polymerases isolated from mesophilic microorganisms have been extensively characterized, but much less is known about the properties of thermostable DNA polymerases. With the introduction of the PCR method of DNA amplification, considerable interest has been focused on the DNA polymerases of thermophilic organisms. A DNA polymerase isolated from $T$. aquaticus has been previously described. ${ }^{(34,35)}$ The enzyme is reported to have an approximate molecular weight of $62,000-68,000$, a temperature optimum of $70-80^{\circ} \mathrm{C}$, and a $\mathrm{pH}$ optimum in the range of 7.8-8.3. Optimal activity is obtained with $60-200$ $\mathrm{mm} \mathrm{KCl}$ and $10 \mathrm{mM} \mathrm{Mg}^{2+}$. Manganese is only $20-50 \%$ effective and shows an optimum of 1-2 mM. The enzyme as isolated by Chien et al. ${ }^{(34)}$ has a specific activity ${ }^{(36)}$ greater than 474.8 units $/ \mathrm{mg}$, whereas the enzyme isolated by Kaledin et al. ${ }^{(35)}$ has a specific activity between 1612 units/mg and 5200 units/mg, depending on the nature of the substrate. In contrast, the $T$. aquaticus DNA polymerase we describe has a molecular weight of 94,000 , and a specific activity of 292,000 units/mg. Optimal polymerization activity is achieved at $75-80^{\circ} \mathrm{C}$, in the presence of $10-55 \mathrm{mM} \mathrm{KCl}$ and $2-3$ $\mathrm{mm} \mathrm{Mg}^{2+}$. Manganese is approximately $80 \%$ as effective and shows an optimum of $0.6 \mathrm{~mm}$. The Stoffel fragment behaves somewhat differently than the fulllength enzyme in activity assays. It has a preference for low ionic strength regardless of template, and has a broader and higher ( $\sim 4 \mathrm{~mm}) \mathrm{Mg}^{2+}$ optimum. The optimum for manganese is also broader; however, it is only $60 \%$ as effective relative to $\mathrm{MgCl}_{2}$.

Based on the physical and biochemical characterization of the polymerases purified by Chien et al. ${ }^{(34)}$ and Kaledin et al., ${ }^{(35)}$ it is unclear whether these proteins are the products of a distinct gene (or genes) from that which encodes the DNA polymerase described here, or are partially purified proteolytic degradation fragments of the same translation product. The Taq DNA polymerase described by Engelke et al. ${ }^{(7)}$ is the translation product of the gene initially identified $^{(5)}$ and further modified as reported in this manuscript. In the expressed protein isolated by Engelke, et al., ${ }^{(7)}$ the first two amino acids encoded for in the native gene (Met-Arg-) were replaced with three vector-encoded amino acids MetAsn-Ser. Expression levels were approximately 3.5-fold lower than those achieved with pLSG5 (Table 2), as determined by activity assays of clarified heattreated extracts. The purification resulted in an enzyme preparation that contained trace contamination from $E$. coli proteins and had a specific activity of 5263 units/mg. A clone expressing a Taq DNA polymerase gene has also been identified by Sagner et al. ${ }^{(6)}$ This clone expresses a 94-kD Taq DNA polymerase that is presumably identical to the polymerase described here. An expression clone producing an active amino-terminally truncated Taq DNA polymerase, KlenTaq, has also been described, ${ }^{(8)}$ with translational initiation occurring at the corresponding $\mathrm{Met}^{236}$ codon of the native gene.

The DNA polymerases from a number of other thermophilic eubacteria have also been isolated and partially characterized (Table 4). These include Bacillus stearothermophilus $(B s t),{ }^{(37,38)}$ Thermus ruber $(T r u),{ }^{(39)} T$. flavus $(T f l),{ }^{(40)} T$. thermophilus (Tth) HB-8, ${ }^{(41,42)}$ and Thermotoga sp. (Tsp) strain FjSS3-B.1. ${ }^{(43)}$ In addition to the eubacteria, thermophilic archaeal DNA polymerases have also been characterized. The Archaea constitute a group of prokaryotes with an intermediate phylogenetic position between eukaryotes and eubacteria. They comprise the most extreme thermophilic organisms known. A DNA polymerase has been purified and characterized from the thermoacidophilic archaeon Sulfolobus acidocaldarius (Sac). ${ }^{(44-46)}$ Similarly, DNA polymerases from Sulfolobus solfataricus $($ Sso $),{ }^{(47)}$ 
TABLE 4 Properties of Thermophilic DNA Polymerases

\begin{tabular}{|c|c|c|c|c|c|c|c|c|}
\hline \multirow[b]{2}{*}{ Enzyme } & \multicolumn{4}{|c|}{ Optima } & \multirow{2}{*}{$\begin{array}{l}\text { Molecular } \\
\text { weight } \\
\left(\times 10^{-3}\right)\end{array}$} & \multirow[b]{2}{*}{$\begin{array}{l}\text { Specific } \\
\text { activity }^{\mathrm{a}}\end{array}$} & \multicolumn{2}{|c|}{$\begin{array}{c}\text { Exonuclease } \\
\text { activity }\end{array}$} \\
\hline & $\mathrm{MgCl}_{2}(\mathrm{mM})$ & $\mathrm{pH}$ & $\mathrm{KCl}(\mathrm{mm})$ & $\begin{array}{c}\text { Temperature } \\
\left({ }^{\circ} \mathrm{C}\right)\end{array}$ & & & $\frac{a}{5^{\prime} \text { to } 3^{\prime}}$ & $3^{\prime}$ to 5 \\
\hline Taq Pol I & 2 & 9.4 & 55 & 80 & 94 & 292,000 & + & - \\
\hline Stoffel fragment & 4 & 8.3 & 10 & 80 & 61.3 & 369,000 & - & - \\
\hline Taq Pol (34) & 10 & 7.8 & 60 & 80 & $63-68$ & $>475$ & - & - \\
\hline Taq Pol (35) & 10 & 8.3 & $100-200$ & 70 & $60-62$ & $1,600-5,200$ & - & - \\
\hline Bst Pol (37) & 30 & 9.0 & ND & 65 & ND & 424 & - & - \\
\hline Bst Pol (38) & 20 & $8-9$ & 270 & 60 & 76 & 16,000 & \pm & - \\
\hline Tru Pol (39) & 2.5 & 9.0 & 15 & 70 & 70 & 8,000 & - & - \\
\hline Tfl Pol (40) & $10-40$ & 10.0 & 50 & 70 & 66 & 12,000 & - & - \\
\hline \multicolumn{9}{|l|}{ Tth Pol (41) } \\
\hline A & ND & ND & ND & 50 & $110-150$ & 58 & - & - \\
\hline $\mathbf{B}$ & ND & ND & ND & 63 & $\sim 110$ & 922 & - & - \\
\hline $\mathrm{C}$ & ND & ND & ND & 63 & $\sim 110$ & 1,380 & - & - \\
\hline Tth Pol (42) & ND & ND & ND & ND & 67 & 4,000 & - & ND \\
\hline Tsp Pol (43) & 10 & $7.5-8.0$ & 0 & $>80$ & 85 & 16 & ND & ND \\
\hline Sac Pol (44) & $0.1-1$ & $6.0-8.0$ & 0 & 65 & 100 & 71,500 & - & + \\
\hline Sac Pol (45) & ND & ND & ND & 70 & 100 & 60,000 & - & - \\
\hline Sso Pol (47) & 3 & 6.8 & 0 & 75 & 110 & 42,360 & - & - \\
\hline Tac Pol (48) & 4 & 8.0 & $5^{\mathrm{b}}$ & 65 & 88 & 17,500 & - & + \\
\hline Mth Pol (52) & $10-20$ & 8.0 & 100 & 65 & 72 & 4,720 & + & + \\
\hline
\end{tabular}

aSpecific activities have been normalized such that one unit equals the amount of activity which will incorporate 10 nmoles of dNTPs into product in $30 \mathrm{~min}$.

${ }^{b} \mathrm{NH}_{4} \mathrm{Cl}$.

Thermoplasma acidophilum (Tac), ${ }^{(48)}$ Thermococcus litoralis (T7i), ${ }^{(49,50)}$ and $P y$ rococcus furiosus $(P f u)^{(51)}$ have been isolated. The purification and characterization of a DNA polymerase from a methanogenic archaeon Methanobacterium thermoautotrophicum (Mth) has also been reported ${ }^{(52)}$

Table 4 shows that considerable variation exists among those thermostable DNA polymerases that have been characterized in the literature. A distinct feature of all these DNA polymerases is that they all appear to be monomeric. Whether or not a multimeric DNA polymerase similar to $E$. coli DNA polymerase III exists in thermophilic bacteria is unknown. It is also unknown whether these polymerases are involved in replication or repair. A substantial difference among the enzymes is the presence or absence of associated exonuclease activities. Only Taq Pol I ${ }^{(53,54)}$ (Table 3), and Mth DNA polymerase ${ }^{(52)}$ have been shown to contain an inherent $5^{\prime}$ to $3^{\prime}$ exonuclease activity, whereas only Tac DNA polymerase, ${ }^{(48)}$ Mth DNA polymerase, ${ }^{(52)}$ Tli DNA polymerase, ${ }^{(49,50)}$ and $P f u$ DNA polymerase ${ }^{(51)}$ have been shown to contain an inherent $3^{\prime}$ to $5^{\prime}$ exonuclease activity. Of the characterized thermostable DNA polymerases, only Mth DNA polymerase resembles $E$. coli DNA polymerase I, in that it contains both a $5^{\prime}$ to $3^{\prime}$ exonuclease and a $3^{\prime}$ to $5^{\prime}$ exonuclease. ${ }^{(52)}$ The lack of any $5^{\prime}$ to $3^{\prime}$ exonucleolytic activity associated with the majority of the thermostable DNA polymerases may reflect a real difference among the enzymes, differences in the sensitivity of the assay procedures, or, alternatively, may be the consequence of proteolytic degradation resulting in an amino-terminal truncation of the protein. Considerable care in purification is required, as DNA polymerases appear to be particularly susceptible to proteolytic cleavage. ${ }^{(44,47,48,52)}$ Preliminary evidence suggests that a 94,000-dalton DNA polymerase purified from $T$ th contains an inherent $5^{\prime}$ to $3^{\prime}$ exonuclease identical with that of Taq Pol I. ${ }^{(55)}$ The absence of an inherent $3^{\prime}$ to $5^{\prime}$ exonuclease activity in a majority of the polymerases may again reflect a real difference between species; alternatively a $3^{\prime}$ to $5^{\prime}$ exonuclease may exist as a separate subunit or auxiliary protein.

A unique feature of Taq Pol $I$ is its exceptional thermostability. This is surprising considering that several of the above-mentioned organisms grow optimally at temperatures considerably higher than Taq; Tsp strain FjSS3-B.1 grows optimally at $80^{\circ} \mathrm{C},{ }^{(43)} \mathrm{Sac}$ grows at temperatures up to $85^{\circ} \mathrm{C}_{r}^{(45)}$ and Sso grows optimally at $87^{\circ} \mathrm{C},{ }^{(47)}$ whereas $T a q$ has an optimum temperature for growth of only $70^{\circ} \mathrm{C} .^{i 56)}$ Yet for those enzymes whose thermostabilities are reported in the literature, Taq Pol I, with an activity half-life of $45-50 \mathrm{~min}$ at $95^{\circ} \mathrm{C}$ and $9 \mathrm{~min}$ at $97.5^{\circ} \mathrm{C}$, is only second in thermostability to that of the truncated Stoffel fragment, with an activity half-life of 21 min at $97.5^{\circ} \mathrm{C}$. In comparison, $T s p$ strain FjSS3-B. 1 has an activity half-life of 7 min at $95^{\circ} \mathrm{C}^{(43)}$ Sac has an activity halflife of less than $15 \mathrm{~min}$ at $90^{\circ} \mathrm{C},{ }^{(45)}$ and Sso has an activity half-life of $5 \mathrm{~min}$ at $90^{\circ} \mathrm{C}{ }^{(47)}$ This extraordinary thermostability makes Taq Pol I especially suited to those applications where repeated incubation at very high temperatures is desired. Subsequent to completion of this manuscript, the thermostability of $\mathrm{Tli}$ DNA polymerase has been described. ${ }^{(57)}$ The polymerase, derived from a hyperthermophilic Archae which grows at temperatures up to $98^{\circ} \mathrm{C}$, has an activity half-life of about $2 \mathrm{hr}$ at $100^{\circ} \mathrm{C}$.

Taq Pol I has many features in common with E. coli DNA polymerase I. Considerable amino acid similarity exists between Taq Pol I and E. coli DNA polymerase $I^{(5,58,59)}$ The amino-termi- 
nal region of Taq Pol I corresponds to the amino-terminal domain of $E$. coli DNA polymerase I shown to contain the 5 ' to $3^{\prime}$ exonuclease activity. ${ }^{(60)}$ The carboxy-terminal region of Taq Pol I corresponds to the $E$. coli DNA polymerase I domain shown to contain DNA polymerase activity. ${ }^{(61)}$ For the $3^{\prime}$ to $5^{\prime}$ exonuclease domain of $E$. coli DNA polymerase $I^{\left({ }^{62)}\right.}$ no meaningful alignment with Taq Pol I was obtained. The domain structure of $E$. coli DNA polymerase I is conserved in Taq Pol I. Similar to the Klenow fragment of $E$. coli DNA polymerase $I_{,}{ }^{(60,63)}$ Stoffel fragment retains all of the DNA polymerase activity of the full-length protein, but is completely devoid of any $5^{\prime}$ to $3^{\prime}$ exonuclease activity. Characterization of the $5^{\prime}$ to $3^{\prime}$ exonuclease activity of the two full-length proteins reveals that the mechanism of exonuclease action is very similar for the two enzymes. ${ }^{(64)}$ Like E. coli DNA polymerase I, Taq Pol I requires a duplex structure for $5^{\prime}$ to $3^{\prime}$ exonuclease activity and is stimulated by concurrent polymerization. ${ }^{65,66)}$ The major difference between the two enzymes, aside from the exceptional thermostability and thermoactivity of Taq Pol I, appears to be the lack of an inherent $3^{\prime}$ to $5^{\prime}$ exonuclease activity in Taq Pol I. Although this is not a unique feature of all thermostable DNA polymerases, as discussed above, it appears to be a common feature among the DNA polymerases isolated to date from thermophilic eubacteria.

Subtle differences exist between the polymerase activity of the Stoffel fragment and full-length Taq Pol I. Whereas the Stoffel fragment is more thermostable than Taq Pol I, it is not as active at temperatures greater than $80^{\circ} \mathrm{C}$ (see Fig. $6)$. This may be due to a difference in the ability of the enzyme to bind to DNA at high temperatures. That a difference in DNA binding exists between the two enzymes is reflected in the approximately 10-fold lower processivity of the Stoffel fragment. ${ }^{(55)}$ This difference in processivity also may explain the observed difference in sensitivity to ionic strength between the enzymes. A low salt concentration increases the stability of the protein-nucleic acid complex and decreases the rate of dissociation of the polymerase from the replicated template, resulting in an increase in processivity. Thus, in low salt the higher processivity results in increased activity on long templates (i.e., primed M13 template). For the replication of short stretches of DNA like those presumably seen with activated salmon sperm DNA template, the decreased dissociation rate of the polymerase-replicated template complex may cancel the gains from increased processivity, and result in a somewhat lower synthesis rate (see Fig. 5A). For the Stoffel fragment, however, with a much lower processivity, the increase in processivity dominates, and maximal activity is seen at low ionic strength with both templates (see Fig. 5B). An increased enzyme-substrate stability in low salt may increase the activity of the Stoffel fragment on activated salmon sperm template by favoring strand-displacement synthesis. Alternatively, the differences between full-length Taq Pol I and the Stoffel fragment observed on activated template may be the result of the effect of ionic strength on the $5^{\prime}$ to $3^{\prime}$ exonuclease activity of Taq Pol I, for which nick-translation synthesis presumably predominates over strand-displacement synthesis. Differences are also apparent in the response of the two enzymes to divalent cations. The Stoffel fragment is optimally active over a broader range of $\mathrm{Mg}^{2+}$ concentrations, but is less active when either $\mathrm{Mn}^{2+}$ or $\mathrm{Co}^{2+}$ is substituted for $\mathrm{Mg}^{2+}$ (see Fig. 4). The truncated Taq DNA polymerase, KlenTaq, was measured to have a twofold lower mutation rate as compared to the full-length enzyme. ${ }^{(8)}$ The model for this comparative increase in fidelity derives from a consideration of the relative processivities of the two forms of the enzyme, and their subsequent abilities to extend a mispaired nucleotide (i.e., lower processivity results in suppression of mismatch extension, thereby decreasing the misincorporation rate of the enzyme). Analogously, the Stoffel fragment may also possess a lower comparative mutation rate.

The differences between the two enzymes can be exploited for a variety of applications. The Stoffel fragment may be preferred for performing dideoxy nucleotide sequencing, where the $5^{\prime}$ to 3 ' exonuclease activity of Taq Pol I may produce unwanted artifacts. The Stoffel fragment also may prove superior in performing the PCR with certain templates that contain stable secondary structure. Extension of a primer on a template strand possessing a hairpin structure creates an ideal substrate for the $5^{\prime}$ to $3^{\prime}$ exonuclease activity of Taq DNA poly- merase at the site of the hairpin. ${ }^{(53,65,66)}$ Extension with Taq Pol I could result in exonucleolytic cleavage of the template strand at the hairpin structure, rather than strand displacement, creating DNA fragments that are incapable of serving as templates in later cycles of the PCR. The Stoffel fragment may be useful in PCR where a large amount of product is desired. Standard PCRs with Taq Pol I reach a plateau stage in late cycle PCR, where product accumulation is no longer exponential. An effect contributing to plateau may be the renaturation of product strands during extension. This could result in a substrate for the $5^{\prime}$ to $3^{\prime}$ exonuclease activity of Taq Pol I, where the renatured strand can be cleaved, and synthesis may proceed under nick-translation conditions, resulting in no net gain in product. The Stoffel fragment, on the other hand, may proceed under strand-displacement conditions, with no destruction of product. The increased thermostability of the Stoffel fragment allows for the amplification of exceptionally G/C-rich targets, where high denaturation temperatures are required. The broader $\mathrm{Mg}^{2+}$ optimum for activity of the Stoffel fragment may prove useful in multiplex PCR, where multiple templates are being amplified simultaneously. ${ }^{(67)}$ Alternatively, in applications such as random mutagenesis $\mathrm{PCR}^{(68)}$ and reverse transcription, ${ }^{(69)}$ where $\mathrm{Mn}^{2+}$ is desired as the divalent cation cofactor, full-length Taq Pol I may prove superior. The $5^{\prime}$ to $3^{\prime}$ exonuclease activity of Taq Pol I can be used in a PCRbased detection system to generate a specific detectable signal concomitantly with amplification. ${ }^{(53)}$ Taq Pol I also may be preferable in the amplification of long templates, where increased processivity may be an advantage, whereas the Stoffel fragment, if shown to have higher fidelity than Taq Pol I, may be preferable for high-fidelity amplifications. The lower processivity of the Stoffel fragment also makes the enzyme useful for the amplification of rare mutant alleles in a background of normal DNA, using allele-specific primers where $3^{\prime}$ mismatch extension is suppressed relative to that of full-length Taq Pol I. ${ }^{(70,71)}$

\section{ACKNOWLEDGMENTS}

We gratefully acknowledge Max Gottesman for providing E. coli strain N6590; Kirk Dakis for technical assistance; Lauri 
Goda, Dragan Spasic, and Corey Levenson for preparation of oligonucleotides; Ken Myambo for DNA sequence analysis; Keith Bauer and Jodi Switzer for fermentation support; Ken Watt and Frank Buschman for amino-terminal sequence analysis and analysis of amino acid composition; Robert Watson for advice and support; Tom Myers, Tom White, John Sninsky, Hamilton Smith, Norman Arnheim, and Ellen Daniell for advice and critical review of the manuscript; Sharon Nilson and Eric Ladner for preparation of figures; and Robin Kurka for preparation of the manuscript.

\section{REFERENCES}

1. Saiki, R.K., S. Scharf, F. Faloona, K.B. Mullis, G.T. Horn, H.A. Erlich, and N. Arnheim. 1985, Enzymatic amplification of $\beta$-globin genomic sequences and restriction site analysis for diagnosis of sickle cell anemia. Science 230: 1350-1354.

2. Mullis, K.B. and F. Faloona. 1987. Specific synthesis of DNA in vitro via a polymerase-catalyzed chain reaction. Methods Enzymol. 155: 335-350.

3. Saiki, R.K., D.H. Gelfand, S. Stoffel, S. Scharf, R. Higuchi, G.T. Horn, K.B. Mullis, and H.A. Erlich. 1988. Primer-directed enzymatic amplification of DNA with a thermostable DNA polymerase. Science 239: 487-491.

4. Innis, M.A., K.B. Myambo, D.H. Gelfand, and M.A.D. Brow. 1988. DNA sequencing with Thermus aquaticus DNA polymerase and direct sequencing of polymerase chain reaction-amplified DNA. Proc. Natl. Acad. Sci. 85: 9436-9440.

5. Lawyer, F.C., S. Stoffel, R.K. Saiki, K. Myambo, R. Drummond, and D.H. Gelfand. 1989. Isolation, characterization, and expression in Escherichia coli of the DNA polymerase gene from Thermus aquaticus. J. Biol. Chem. 264: 6247-6437.

6. Sagner, G., R. Rüger, and C. Kessler. 1991. Rapid filter assay for the detection of DNA polymerase activity: Direct identification of the gene for the DNA polymerase from Thermus aquaticus. Gene 97: 119-123.

7. Engelke, D.R., A. Krikos, M.E. Bruck, and D. Ginsburg. 1990. Purification of Thermus aquaticus DNA polymerase expressed in Escherichia coli. Anal. Biochem. 191: 396-400.

8. Barnes, W.M. 1992. The fidelity of Taq polymerase catalyzing $\mathrm{PCR}$ is improved by an N-terminal deletion. Gene 112: 2935.

9. Cole, G.E., P.C. McCabe, D. Inlow, D.H. Gelfand, A. Ben-Bassat, and M.A. Innis. 1988. Stable expression of Aspergillus awamori glucoamylase in distiller's yeast. Biotechnology 6: 417-421.
10. Meselson, M. and R. Yuan. 1968. DNA restriction enzyme from E. coli. Nature 217: 1110-1114.

11. Miller, J.H. 1972. Generalized transduction; use of P1 in strain construction. In Experiments in molecular genetics (ed. J.H. Miller), pp. 201-205. Cold Spring Harbor Laboratory, Cold Spring Harbor, New York.

12. Wang, A.M., A.A. Creasey, M.B. Ladner, L.S. Lin, J. Strickler, J.N. Van Arsdell, R. Yamamoto, and D F. Mark. 1985. Molecular cloning of the complementary DNA for human tumor necrosis factor. Science 228: $149-154$

13. Moore, S.K. and E. James. 1976. Purification and electrophoretic assay of T4-induced polynucleotide ligase for the in vitro construction of recombinant DNA molecules. Anal. Biochem. 75: 545-554.

14. Sambrook, J., E.F. Fritch, and T. Maniatis. 1989. Molecular cloning: A laboratory man ual, 2nd edition. Cold Spring Harbor Laboratory Press, Cold Spring Harbor, New York.

15. Beaucage, S.L. and M.G. Caruthers. 1981. Deoxynucleoside phosphoramidites-a new class of key intermediates for deoxy. polynucleotide synthesis. Tetrahedron Lett. 22: 1859-1862.

16. Sinha, N.D., J. Biernat, J. McManus, and H. Köster. 1984. Polymer support oligonucleotide synthesis XVIII: Use of $\beta$-cyanoethyl- $N, N$-dialkylamino- $/ N$ morpholino phosphoramidite of deoxynucleosides for the synthesis of DNA fragments simplifying deprotection and isolation of the final product. Nucleic Acids Res. 12: 4539-4557.

17. Livingston, D.M., D.C. Hinkel, and C.C Richardson. 1975. Deoxyribonucleic acid polymerase llI of Escherichia coli: Purification and properties. J. Biol. Chem. 250: $461-469$.

18. Long, C.M., M.-J. Virolle, S.-Y. Chang, S Chang, and M.J. Bibb. 1987. $\alpha$-Amylase gene of Streptomyces limosus: Nucleotide sequence, expression motifs, and amino acid sequence homology to mammalian and invertebrate $\alpha$-amylases. J. Bacteriol. 169: 5745-5754.

19. Hanahan, D. 1983. Studies on transformation of Escherichia coli with plasmids. J. Mol. Biol. 166: 557-580.

20. Birnboim, H.C. and J. Doly. 1979. A rapid alkaline extraction procedure for screening recombinant plasmid DNA. Nucleic Acids Res. 7: 1513-1523.

21. Sanger, F., S. Nicklen, and A.R. Coulson. 1977. DNA sequencing with chain-terminating inhibitors. Proc. Natl. Acad. Sci. 74: 5463-5467.

22. Fritz, H.-J., J. Hohlmaier, W. Kramer, A. Ohmayer, and J. Wippler. 1988. Oligonucleotide-directed construction of mutations: A gapped duplex DNA procedure without enzymatic reactions in vitro. $\mathrm{Nu}$ - cleic Acids Res. 16: 6987-6999.

23. Woods, D.E., A.F. Markham, A.T. Ricker, G. Goldberger, and H.R. Colten. 1982. Isolation of cDNA clones for the human complement protein factor $\mathrm{B}$, a class III major histocompatibility complex gene product. Proc. Natl. Acad. Sci. 79: 56615665.

24. Vogel, H.J. and D.M. Bonner. 1956. Acetylornithinase of Escherichia coli: Partial purification and some properties. J. Biol. Chem. 218: 97-102.

25. Skoog, D.A. and D.M. West. 1976. Fundamentals of analytical biochemistry, 3rd edition, pp. 737-739.

26. Piatak, M., J.A. Lane, W. Laird, M.J. Bjorn, A. Wang, and M. Williams. 1988. Expression of soluble and fully functional ricin A chain in Escherichia coli is temperaturesensitive. J. Biol. Chem. 263: 4837-4843.

27. Lin, T.-C., J. Rush, E.K. Spicer, and W.H. Konigsberg. 1987. Cloning and expression of T4 DNA polymerase. Proc. Natl. Acad. Sci. 84: 7000-7004.

28. Innis, M.A. and D.H. Gelfand. 1990. Optimization of PCRs. In PCR protocols: $A$ guide to methods and applications (ed. M.A. Innis, D.H. Gelfand, J.J. Sninsky, and T.J. White), pp. 3-12 Academic, San Diego, California.

29. Tabor, S., H.E. Huber, and C.C. Richardson. 1987. Escherichia coli thioredoxin confers processivity on the DNA polymerase activity of the gene 5 protein of bacteriophage T7. J. Biol. Chem. 262: 16212-16223.

30. Englund, P.T., J.A. Huberman, T.M. Jovin, and A. Kornberg. 1969. Enzymatic synthesis of deoxyribonucleic acid: XXX. Binding of triphosphates to deoxyribonucleic acid polymerase. J. Biol. Chem. 244: 3038-3044.

31. Kelley, W.S. and K.H. Stump. 1979. A rapid procedure for isolation of large quantities of Escherichia coli DNA polymerase 1 utilizing a $\lambda$ polA transducing phage. J. Biol. Chem. 254: 3206-3210.

32. Hori, K., D.F. Mark, and C.C. Richardson. 1979. Deoxyribonucleic acid polymerase of bacteriophage T7: Purification and properties of the phage-encoded subunit, the gene 5 protein. J. Biol. Chem. 254: 11591-11597.

33. Ben-Bassat, A., K. Bauer, S.-Y. Chang, K. Myambo, A. Boosman, and S. Chang. 1987. Processing of the initiation methionine from proteins: Properties of the $E s$ cherichia coli methionine peptidase and its gene structure. J. Bacteriol. 169: 751757.

34. Chien, A., D.B. Edgar, and J.M. Trela. 1976. Deoxribonucleic acid polymerase from the extreme thermophile Thermus aquaticus. J. Bacteriol. 127: 1550-1557.

35. Kaledin, A.S., A.G. Slyusarenko, and S.I. Gorodetskii. 1980. Isolation and properties of DNA polymerase from extremely 
thermophilic bacterium Thermus aquaticus YT1. Biokhimiya 45: 644-651.

36. Specific activities have all been normalized such that one unit is defined as that amount of activity that will incorporate 10 nmoles of dNTPs into product in 30 $\min$.

37. Stenesh, J. and B.A. Roe. 1972. DNA polymerase from mesophilic and thermophilic bacteria: I. Purification and properties of DNA polymerase from Bacillus licheniformis and Bacillus stearothermophilus. Biochim. Biophys. Acta 272: 156166.

38. Kaboev, O.K., L.A. Luchkina, A.T. Akhmedov, and M.L. Bekker. 1981. Purification and properties of deoxyribonucleic acid polymerase from Bacillus stearothermophilus. J. Bacteriol. 145: 21-26.

39. Kaledin, A.S., A.G. Slyusarenko, and S.I. Gorodetskii. 1982. Isolation and properties of DNA polymerase from the extremely thermophilic bacterium Thermus ruber. Biokhimiya 47: 1785-1791.

40. Kaledin, A.S., A.G. Slyusarenko, and S.I. Gorodetskii. 1981. Isolation and properties of DNA polymerase from the extremely thermophilic bacterium Thermus flavus. Biokhimiya 46: 1576-1584.

41. Rüttimann, C., M. Cotorás, J. Zaldívar, and R. Vicuña. 1985. DNA polymerases from the extremely thermophilic bacterium Thermus thermophilus HB-8. Eur. J. Biochem. 149: 41-46.

42. Carballeira, N., M. Nazabal, J. Brito, and O. Garcia. 1990. Purification of a thermostable DNA polymerase from Thermus thermophilus HB8, useful in the polymerase chain reaction. BioTechniques 9: 276-281.

43. Simpson, H.D., T. Coolbear, M. Vermue, and R.M. Daniel. 1990. Purification and some properties of a thermostable DNA polymerase from a Thermotoga species. Biochem. Cell Biol. 68: 1292-1296.

44. Klimczak, L.J., F. Grummt, and K.J. Burger. 1985. Purification and characterization of DNA polymerase from the archaebacterium Sulfolobus acidocaldarius. Nucleic Acids Res. 13: 5269-5282.

45. Elie, C., S. Salhi, J.-M. Rossignol, P. Forterre, and A.-M. de Recondo. 1988. A DNA polymerase from a thermoacidophilic archaebacterium: Evolutionary and technological interests. Biochem. Biophys. Acta 951: 261-267.

46. Salhi, S., C. Elie, P. Forterre, A.-M. de Recondo, and J.-M. Rossignol. 1989. DNA polymerase from Sulfolobus acidocaldarius: Replication at high temperature of long stretches of single-stranded DNA. $J$. Mol. Biol. 209: 635-644.

47. Rella, R., C.A. Raia, F.M. Pisani, S. D'Auria, R. Nucci, A Gambacorta, M. De Rosa, and M. Rossi. 1990. Purification and properties of a thermophilic and thermostable DNA polymerase from the archaebacte- rium Sulfolobus solfataricus. Ital. J. Biochem. 39: 83-99.

48. Hamal, A., P. Forterre, and C. Elie. 1990. Purification and characterization of a DNA polymerase from the archaebacterium Thermoplasma acidophilum. Eur. J. Biochem. 190: 517-521.

49. Matilla, P., J. Korpela, T. Tenkanen, and K. Pitkänen. 1991. Fidelity of DNA synthesis by the Thermococcus litoralis DNA polymerase-an extremely heat stable enzyme with proofreading activity. Nucleic Acids Res. 19: 4967-4973.

50. Perler, F.B., D.G. Comb, W.E. Jack, L.S Moran, B. Qiang, R.B. Kucera, J. Benner, B.E. Slatko, D.O. Nwankwo, S.K. Hempstead, C.K.S. Carlow, and H. Jannasch. 1992. Intervening sequences in an Archaea DNA polymerase gene. Proc. Natl. Acad. Sci. 89: 5577-5581.

51. Lundberg, K.S., D.D. Shoemaker, M.W.W. Adams, J.M. Short, J.A. Sorge, and E.J. Mathur. 1991. High-fidelity amplification using a thermostable DNA polymerase isolated from Pyrococcus furiosus. Gene 108: 1-6.

52. Klimczak, L.J., F. Grummt, and K.J. Burger. 1986. Purification and characterization of DNA polymerase from the archaebacterium Methanobacterium thermoautotrophicum. Biochemistry 25: 4850 4855.

53. Holland, P.M., R.D. Abramson, R. Watson, and D.H. Gelfand. 1991. Detection of specific polymerase chain reaction product by utilizing the $5^{\prime}$ to $3^{\prime}$ exonuclease activity of Thermus aquaticus DNA polymerase. Proc. Natl. Acad. Sci. 88: 72767280 .

54. Longley, M.J., S.E. Bennett, and D.W. Mosbaugh. 1990. Characterization of the $5^{\prime}$ to $3^{\prime}$ exonuclease associated with Thermus aquaticus DNA polymerase. Nucleic Acids Res. 18: 7317-7322.

55. R.D. Abramson, unpublished data.

56. Brock, T.D. and H. Freeze. 1969. Thermus aquaticus gen. n. and sp. n., a non-sporulating extreme thermophile. J. Bacteriol. 98: 289-297.

57. Kong, H., R.B. Kucera, and W.E. Jack. 1993. Characterization of a DNA polymerase from the hyperthermophile Archaea Thermococcus litoralis. J. Biol. Chem. 268: 1965-1975.

58. Delarue, M., O. Poch, N. Tordo, D. Moras, and P. Argos. 1990. An attempt to unify the structure of polymerases. Prot. Eng. 3: 461-467.

59. Blanco, L., A. Bernad, M.A. Blasco, and M. Salas. 1991. A general structure for DNAdependent DNA polymerases. Gene 100: 27-38.

60. Brutlag, D., M.R. Atkinson, P. Setlow, and A. Kornberg. 1969. An active fragment of DNA polymerase produced by proteolytic cleavage. Biochem. Biophys. Res. Commun. 37: 982-989.
61. Freemont, P.S., D.L. Ollis, T.A. Steitz, and C.M. Joyce. 1986. A domain of the Klenow fragment of Escherichia coli DNA polymerase I has polymerase but no exonuclease activity. Proteins: Struct. Funct. Genet. 1: 66-73.

62. Derbyshire, V., P.S. Freemont, M.R. Sanderson, L. Beese, J.M. Friedman, C.M. Joyce, and T.A. Steitz. 1988. Genetic and crystallographic studies of the 3',5'-exonucleolytic site of DNA polymerase I. Science 240: 199-201.

63. Klenow, H and I. Henningsen. 1970. Selective elimination of the exonuclease activity of the deoxyribonucleic acid polymerase from Escherichia coli B by limited proteolysis. Proc. Natl. Acad. Sci. 65: 168175.

64. R.D. Abramson and D.H. Gelfand, in preparation.

65. Deutscher, M.P. and A. Kornberg. 1969. Enzymatic synthesis of deoxyribonucleic acid: XXIX. Hydrolysis of deoxyribonucleic acid from the 5' terminus by an exonuclease function of deoxyribonucleic acid polymerase. J. Biol. Chem. 244: 3029-3037.

66. Kelly, R.B., N.R. Cozzarelli, M.P. Deutscher, I.R. Lehman, and A. Kornberg. 1970. Enzymatic synthesis of deoxyribonucleic acid: XXXII. Replication of duplex deoxyribonucleic acid by polymerase at a single strand break. J. Biol. Chem. 245: 39-45.

67. Chamberlain, J.S, R.A. Gibbs, J.E. Ranier, P.N. Nguyen, and C.T. Caskey. 1988. Deletion screening of the Duchenne muscular dystrophy locus via multiplex DNA amplification. Nucleic Acids Res. 16: 11141-11156.

68. Leung, D.W., E. Chen, and D.V. Goeddel. 1989. A method for random mutagenesis of a defined DNA segment using a modified polymerase chain reaction. Technique 1: 11-15.

69. Myers, T.W. and D.H. Gelfand. 1991. Reverse transcription and DNA amplification by a Thermus thermophilus DNA polymerase. Biochemistry 30: 7661-7666.

70. Huang, M-M., N. Arnheim, and M. Goodman. 1992. Extension of base mispairs by Taq DNA polymerase: Implications for single nucleotide discrimination in PCR. Nucleic Acids Res. 20: 4567-4573.

71. Tada, M., M. Omata, S. Kawai, H. Saisho, M. Ohto, R.K. Saiki, and J.J. Sninsky, in preparation.

Received January 29, 1993; accepted in revised form March 25, 1993. 


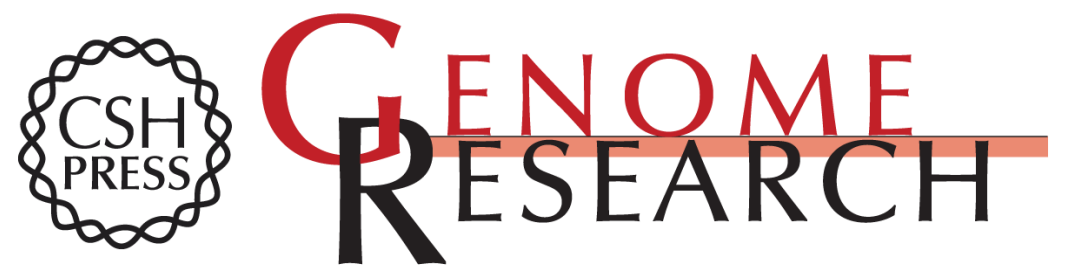

\section{High-level expression, purification, and enzymatic characterization of full-length Thermus aquaticus DNA polymerase and a truncated form deficient in 5' to 3 ' exonuclease activity.}

F C Lawyer, S Stoffel, R K Saiki, et al.

Genome Res. 1993 2: 275-287

Access the most recent version at doi:10.1101/gr.2.4.275

References This article cites 63 articles, 26 of which can be accessed free at: http://genome.cshlp.org/content/2/4/275.full.html\#ref-list-1

\section{License}

Email Alerting

Receive free email alerts when new articles cite this article - sign up in the box at the Service top right corner of the article or click here.

\section{Affordable, Accurate Sequencing.}

